Article

\title{
Spaces of Dependence and Emancipation in Architectural and Urban Narration, a Case Study: Plac Żołnierza Polskiego and Plac Solidarności in Szczecin
}

\author{
Izabela Kozłowska $^{1, *(1)}$ and Eryk Krasucki ${ }^{2}$ (1) \\ 1 Faculty of Architecture, West Pomeranian University of Technology, Żołnierska 50, 71-210 Szczecin, Poland \\ 2 Faculty of Humanities, University of Szczecin, al. Papieża Jana Pawła II 22a, 70-453 Szczecin, Poland; \\ eryk.krasucki@usz.edu.pl \\ * Correspondence: izabela.kozlowska@zut.edu.pl
}

Citation: Kozłowska, Izabela, and Eryk Krasucki. 2021. Spaces of

Dependence and Emancipation in

Architectural and Urban Narration, a Case Study: Plac Żołnierza Polskiego and Plac Solidarności in Szczecin. Arts 10: 19. https://doi.org/ 10.3390/arts10010019

Academic Editor: Hans Morgenthaler

Received: 11 January 2021

Accepted: 2 March 2021

Published: 5 March 2021

Publisher's Note: MDPI stays neutral with regard to jurisdictional claims in published maps and institutional affiliations.

Copyright: (c) 2021 by the authors. Licensee MDPI, Basel, Switzerland. This article is an open access article distributed under the terms and conditions of the Creative Commons Attribution (CC BY) license (https:// creativecommons.org/licenses/by/ $4.0 /)$.

\begin{abstract}
Central and Eastern European countries were subjugated to the Soviet Union in the second half of the 20th century. In this new political environment, defined as the period of dependency, the concept of space gained a new denotation as a space of dependence, in both social and physical terms. The political changes that took place after 1989 enabled these spaces to be emancipated. In this work, we aim to delineate the complex relationship between architecture and politics from the perspective of spaces of dependence and their emancipation. Through a case study of two squares, plac Żołnierza Polskiego (the Square of the Polish Soldier) and plac Solidarności (Solidarity Square) in Szczecin, we gained insights into the processes and strategies that promoted their evolution into spaces of emancipation within architectural and urban narratives. Szczecin's space of dependence was created by an authoritarian state that had a monopoly on defining architecture and urban planning in the country and the state as a whole. In a process orchestrated by economic factors, as well as the scale of architectural and urban degradation, the squares under discussion have transitioned from spaces of dependency to spaces of emancipation. As a result, an architectural-urban structure characterized by new cultural and identity values has been created.
\end{abstract}

Keywords: politics; architecture; urban history; Western Pomerania; social space; dependence space; emancipation space; 'Recovered Territories'; Stettin/Szczecin

\section{Introduction}

The end of the Second World War heralded a new political order in Central and Eastern Europe, subordinating this region to the influence of the Soviet Union. The imperial dependence and post-dependence experience of Central and Eastern European nations were recognized in the 1990s by numerous researchers and situated within a broader post-colonial context (Kubiak 2018; Kołodziejczyk 2013; Dettloff 2012; Friedrich 2012; Kołodziejczyk 2011; Bakuła 2011; Omilanowska 2010; Lisiak 2009; Skórczewski 2008; Golinczak 2008; Thompson 2005; Cavanagh 2004; Janion 2003; Cavanagh 2003; Moore 2001; Thompson 2000; Kiossev 1999; Szkudlarek 1993, 1995). Special interest was paid to Poland's 'Recovered Territories' (Western and Northern Lands (WNL)) (In Polish scientific literature, the term 'Recovered Territories' is considered to be a propaganda concept, so nowadays this area is referred to as the Western and Northern Lands (WNL). The term describes the territories granted to Poland after the Second World War by the resolution of the Potsdam Conference), which-according to the post-war political narration imposed by the Soviet Union-was settled by new Polish residents after the German population had been displaced (Sakson 2020, pp. 7-43). In such a political context, a space of dependence developed which contained both physical and social layers of meaning. The political changes that took place in Poland after 1989 gave rise to the emancipation of the space. 
This work examines the complex relationship between architecture and politics from the perspective of these spaces.

Despite being peripheral in its character, Szczecin is an ideal choice for our study. Its borderland character and its influence on changing political affiliations allow us to present the issues from a broader perspective, which will include the social and political mechanisms influencing its architecture and urban planning.

The aim of this study is to investigate the relationship between architecture and politics from the point of view of both dependence and emancipation. This article attempts to describe the processes unfolding in these spaces and the strategies (cultural, identity, architectural, and urban) that have enabled a space of dependence to evolve into a space of emancipation.

\section{Materials and Methods}

The objectives of this research were achieved by a case study and a comparative methodology that collated parameters highlighting the similarities and differences between urban spaces examined at different stages of their historical development. An analysis of the collected data through inductive reasoning helped us to draw general conclusions.

Two urban spaces were selected for the case study: plac (Plac $=$ Pl. square) Żołnierza Polskiego (the Square of the Polish Soldier, formerly Königsplatz) and plac Solidarności (Solidarity Square) in Szczecin, Poland. The Szczecin agglomeration was selected due to its location in the 'Recovered Territories', as well as its 'borderland' character, which resulted in a hybrid 'historical culture.' (Contemporary scientific discourse defines 'historical culture' as an examination of the past-present relationship that promotes the "understanding of mechanisms used by groups to develop references to the past reality (in this case, urban community), its instrumentalization and motives to maintain remembrance of specific past events" (Rajewski 2013, p. 358). In Germany, for instance, 'historical culture' has been studied by Jan Assmann and Peter Oliver Loew, whereas in Poland, the relevant research has been carried out by Jerzy Maternicki, Barbara Szacka, and Andrzej Szpociński.) The city squares, regarded as "spatial frames for citizens' social activities, are an important identification factor in the human-city relationship" (Paszkowski 2008, p. 44). For these reasons, they were selected as the main focus of this study.

Our analysis compares the spatial elements and parameters of the urban structure of a historic city. Elements of the concave structure were studied, such as the urban network, urban blocks, buildings, as well as the convex structure based on the system of open spaces, the system of streets, and the system of distinctive squares. This study defines formal and semiotic features while referring to the traditions of place and object (traditional use, formal and functional solutions, and materials used) and typical form signs (accent, dominant, or urban interior artifacts as motifs identifying the urban space) (Paszkowski 2008, pp. 34-46; Hasselgren 1972).

The study of architectural and urban structures and forms in historical terms, in connection with the study of 'in-between' space-the space of dependence and emancipationallows for the definition of new research fields. Extending the scope of architecture and urban development to include a form of discourse taken from the humanities, geographical, anthropological and social sciences open up new opportunities for the architectural historian, which express themselves in questions that bring us closer to the critical understanding of the essence of architecture (Lorne 2017; Schneider and Till 2009; Lees 2001; Archer 2005; Goss 1988). The transdisciplinary character of this study supports our understanding of the complex sociopolitical relations in the 'Recovered Territories' after 1945 and 1989. This approach to the question enables us to grasp the correlations between political myths, political symbols, and the design solutions adopted to create the 'material' urban space. Therefore, apart from architectural and urban terms, terminology taken from the humanities and social sciences is used. The latter originates from post-dependence (post-colonial) studies, historical culture, and site of memory. 
The impulse to carry out this study originated from research implemented by the Polish Post-dependence Studies Centre (PPSC). Since 2009, the PPSC has described various forms of 'the emancipation of the subordinated' promoted by Polish philology academic communities by organizing conferences and publishing monographs via the Universitas Publishing House. (For more about the activity of the Polish Post-dependence Studies Centre (PPSC), see http:/ / www.cbdp.polon.uw.edu.pl/ (accessed on 1 November 2020). The PPSC published eight volumes on dependencies, of which those particularly relevant for this study are: Kultura po przejściach, osoby z przeszłościa. Polski dyskurs postzależnościowykonteksty i perspektywy badawcze, vol. 1, edited by Ryszard Nycz, Universitas, Kraków 2011, ISBN: 97883-242-1317-7; '(Po) zaborach, (p)o wojnie, (p)o PRL', Polski dyskurs postzależnościowy dawniej i dziś, vol. 3, edited by Hanna Gosk, Ewa Kraskowska, Universitas, Kraków 2013, ISBN: 97883-242-2244-5; Historie, społeczeństwa, przestrzenie dialogu. Studia postzależnościowe w perspektywie porównawczej, vol. 4, edited by Hanna Gosk, Dorota Kołodziejczyk, Universitas, Kraków 2014, ISBN: 97883-242-2360-2.)

While establishing the status of our research, several recent urban studies were found to be noteworthy. These focused on the transformation from authoritarian to democratic forms of government, and the search for identity and revitalization of cities in Central and Eastern Europe (Czaplicki 2003; Schlögel 2001; Ackermann 2010). The publications on cities in the 'Recovered Territories' are particularly interesting: the historical research includes studies by Loewe on Gdańsk (2012), Thum on Wrocław (2013), and Musekamp on Szczecin (2015). More importantly, these publications were issued by German historians. Their common basis is les lieux de mémoire (or site of memory) (Nora 1984). Colonial and post-colonial aspects in the city space of Szczecin were examined by Praczyk (2015). The publications focus on urban issues from the point of view of social sciences. This paper, however, extends the scope of the study of urban space to include architecture and urban planning.

\section{Spaces of Dependence and Emancipation: A Case Study}

The origin of the present-day plac Żołnierza Polskiego (formerly Königsplatz) is linked to the modern Prussian fortifications surrounding Szczecin which were constructed after Western Pomerania (the Duchy of Pomerania) was taken over by the Kingdom of Prussia in 1713. The political arrangement was finally sealed by the Stockholm Peace Treaty of 1720 (Labuda 1994, p. 454). Western Pomerania fell under the military, administrative, and cultural control of the centralised Prussian monarchy, a monarchy that gradually erased the traces of previous rulers (Pomeranian dukes, Kingdom of Sweden).

Until WWII, Stettin (Szczecin) was an important German urban center with a German cultural identity. The war inflicted heavy damage on it, and $60-70 \%$ of the urban structure was obliterated (Kunicki and Ławecki 2015, p. 36).

According to the decisions taken during the Yalta Conference, Stettin fell within the strip of the so-called 'Recovered Territories' gained by Poland in 1945 as 'compensation' for territories lost in the Eastern Borderlands. It was an unprecedented situation, since the destroyed architectural and urban structure abandoned by previous occupants was taken over by Polish settlers/expatriates/displaced people. This political decision stamped its mark on the cities in the 'Recovered Territories' by initiating the process of 'cultural assimilation' (Musekamp 2015, p. 159), the 'symbolic colonisation of the city' (Praczyk 2015, p. 125) by Poles who moved there after 1945. The process of cultural assimilation of the city progressed in the shadow of the Soviet universum (Oseka 2007). Recently, the concept of dependence on the Soviet Union, previously referred to as Communist and post-Communist forms of dependence, has begun to appear in Polish scientific discourse in terms of colonial mechanisms (Praczyk 2015; Lisiak 2009). This is based on the conviction that the "use of additional postcolonial perspective supports deeper understanding of complex identities (i.e., identities of communist cities in Central Europe)" (Lisiak 2009, p. 138).

In the case of the towns and cities of the 'Recovered Territories,' another possible understanding of their urban identities can be achieved by thinking in terms of palimpsests 
(Przybył-Sadowska et al. 2016, p. 87), or the cultural, ideological, and symbolic references superimposed by the new inhabitants on the previous German architectural and urban structure.

The hybrid nature and multiple morphological and semiotic tiers of Szczecin's urban space can be used as a model of the interdependencies between architecture and politics in the study of dependency and emancipation strategies. To be able to read the complex spatial and social relations of 1945-1989 and the post-1989 emancipation, we should first identify the components of the urban and formal semiotic system in order to determine the significance of town squares, the processes involved in their construction, and their resulting transformation while making reference to their historical origin.

\subsection{Space-Background}

In this article's title, in the research goals as formulated and the research undertaken, the concept of space is used many times. The term 'space' itself is a concept with many meanings, having various connotations depending on the context in which it appears. Space understood materially is an abstract idea (mathematical), a property of matter (physical), the natural environment (natural, geographic), and the basic quantity and property of all things, objective and experientially empirical (philosophy). "Finally, it is a human, anthropogenic, cultural and social creation, and thus created by individuals, groups and (social, cultural) human communities" (Jałowiecki [1988] 2010, p. 19). A similar semantic capacity characterizes the space of plac Żołnierza Polskiego and plac Solidarności in Szczecin. A juxtaposition of its possible interpretations reveals the multidimensionality and relational nature of the structure under study. The collection of these interpretations is presented below, grouped into the following categories:

- Physical space: space in architecture-urban space; public space-private space; cultural space. In this category, space can be defined as a material and physical structure. According to the dictionary definition, urban space "refers to several urban areas and their related multicentric municipalities forming a whole in a single stretch." (Definition quoted from the National Institute of Statistics and Economic Studies, which 'collects, analyzes and disseminates information on the French economy and society': https://www.insee.fr/en/metadonnees/definition/c1074 (accessed on 8 February 2021).) One of the many definitions of space in architecture (Üngür 2011) characterizes it as "organised and shaped in real forms necessary to satisfy material and spiritual human needs" (Niezabitowska 2006). Another definition connects space with sociological areas, and describes it as the interior and exterior space of a building, formed as a result of spatial relationships with other buildings and social relationships (Goss 1988; Hillier and Hanson 1984; Tuan 1983). In terms of morphology, public space is "a place accessible to all citizens, for their use and enjoyment" (Jackson 1985). Private place "is open to those permitted by law or custom" (Birch 2007, p. 118; Francis 1989). Cultural space is: "a special type of public space, characterised by the presence of cultural heritage values or contemporary cultural goods, and by existing or potential opportunities for the creation of cultural functions. These may be complexes of buildings, urban interiors or a series of streets." (Pazder 2008, p. 21)

- Political space: socialist city space-post-socialist city space; dependency space-postdependency space. Space classified in this way is determined by the political situation, which is a factor influencing the physical space; we thus define the space of a socialist city as an urban area which, as a result of the political and economic transformation of the 1990s, is subject to the process of freeing itself from the features of a socialist city (Grabkowska 2017). (Definition quoted from the glossary of terms of socioeconomic geography (available online): http:/ /www.edupedia.pl/words/index/show/292003 _slownik_pojec_geografia_spolecznoekonomycznej-miasto_postsocjalistyczne.html (accessed on 8 February 2021)). With regard to the space of dependence, this term should be interpreted as a political state of the territory's dependence (as in the case 
study discussed above, concerning the Soviet Union), as opposed to post-dependence understood as freeing oneself from a political hegemon (Praczyk 2015).

- Social space: colonial space-post-colonial space; dependency space-post-dependency space; dependency space-emancipation space; space of production-space of consumption-space of symbolism-space of exchange. In Polish scientific discourse, the colonial and post-colonial space is identified with the space of dependence and post-dependence (Praczyk 2015; Kołodziejczyk 2013; Nycz 2011; Kołodziejczyk 2011; Bakuła 2011). However, there are differences between these concepts. Colonizers and colonized function together in space, creating complex mutual relations and dividing it among themselves in various ways (Praczyk 2015, p. 124; Kotkin 2005, pp. 126-36; Hannertz 2006, pp. 141-92) while the space of dependency, read in political terms, is not shared physically with the colonizer. The research tools used by post-colonial studies (categories: difference, inferiority and taming) have successfully been applied to Polish realities, enabling the nuanced specificity of the space of dependency to be extracted (Praczyk 2015). The very term 'post-dependency' was defined by Ryszard Nycz in 2011 as part of the 'Polish post-dependency discourse', understood as a set of: "significant, institutionalised practices of articulation-organising human experience, identity projects, social, political and cultural relations, an axiological and symbolic community imaginarium, forms of perceiving reality-which were undertaken after the dependency had ceased, while at the same time showing traces of it almost de rigeur." (Nycz 2011, p. 8) The process of emancipation initiated before the dependency constitute the space of dependence as "a closed space of supervision, subordination and incapacitation"; and the space of emancipation, in opposition to it, as "an open space of choice, self-creation, inventive action" (Nycz 2011, p. 8). To understand the historical, social and spatial condition of space, dependence and emancipation, one should cite the theoretical context based on the interpretation of Lefebvre's production of space theory (Lefebvre [1974] 1991), developed by Harvey (2012) and Soja (1996). Lefebvre defined it thus: "(Social) space is a (social) product ... the space thus produced also serves as a tool of thought and of action ... in addition to being a means of production it is also a means of control, and hence of domination, of power" (Lefebvre [1974] 1991, p. 26), forming his theory in the triad: spatial practice, representations of Space, space of representation. Lefebvre also proposed a new way of thinking about the city, urban strategies and social practices, describing it as 'the right to the city'. Within the proclaimed manifesto, he distinguished the basic theoretical concepts: structure, function and form (Lefebvre 1996). Jałowiecki also refers to the social production of space, characterizing the following elements of social space: forms-an area with a specific purpose and function, with the accompanying material tools and equipment (space: production, consumption, power, symbolism and exchange); determinants-the conditions for the production of space (universal barriers, development of techniques and technologies, relations of subordination, values and categories of culture); and actors-persons producing space according to their interests, ideology and needs (Jałowiecki [1988] 2010, pp. 37-50).

The space of dependency-post-dependency is classified into two areas within which it can be defined, giving these spaces a political and social meaning.

\subsection{Spatial Structure}

\subsubsection{Urban and Formal-Semiotic Components}

\section{- $\quad$ Plac Żołnierza Polskiego in Szczecin}

Nowadays, plac Żołnierza Polskiego differs from its original pre-war arrangement. The architectural and urban analysis also covers plac Solidarności, which was developed at the former location of a residential quarter adjacent to plac Żołnierza Polskiego.

The development of Prussian fortifications in Stettin (Szczecin) began in 1724 after the city had been taken from Sweden. By about 1734, the medieval moats had been backfilled, and the city walls dating from the end of the 13th century were demolished. Along the 
northern fortification line, between the Peter III, Mühle IV, and Kavalier V bastions, White Parade Square (Weiße Paradeplatz) was created (Kozłowska 2007, pp. 39-40). It was one of two modern squares used for military drills and parades by the Prussian garrison stationed in the Stettin stronghold. Investment by the Prussian crown enhanced the visual appeal of the square from the side of the city, with a uniform style of buildings. The stronghold of Stettin became symbolic of Prussia's domination of the South Baltic Sea Region. New buildings only reaffirmed Prussian rule of the 'newly acquired Pomerania' (Musekamp 2015, p. 278). The first element of the new structure was the King's Gate (1725 Anklamer Thor, 1840 Königstor), designed by Gerhard Cornelius Walrave, a distinguished Dutch architect and fortification planner, in the service of the Prussian King Frederick Wilhelm I (Słomiński 1987, p. 111; Kozłowska 2007, pp. 39-40). The gate's design followed traditional Dutch baroque classicism (northern, baroque classicism), defined in German literature as the Prussian baroque (Fritsch 1931, p. 390; Rzempołuch 2002, p. 211) (Figure 1).

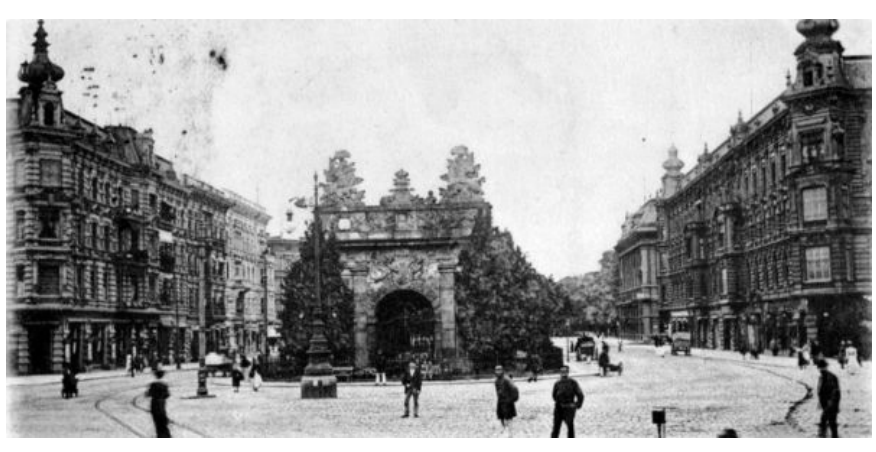

(a)

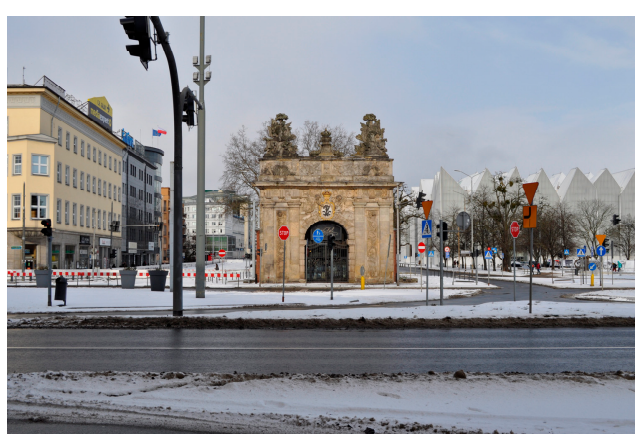

(b)

Figure 1. The King's Gate in Szczecin, both photos were taken from a similar place, and show the southern facade of the building: (a) before 1939, the building was symmetrically surrounded by perimeter blocks with eclectic-style tenement houses from the turn of the 20th century (source: sedina.pl); (b) nowadays, the composition of the King's Gate surroundings has been 'disturbed' as a result of the liquidation of the quarter, which was located on the site of the present Solidarity Square. In the foreground, one can see the extension of the road communication system of the Castle Route (Trasa Zamkowa) (source: created by author).

The same style can be found in the Landeshaus, the seat of the Pomeranian States Parliament, which contained residential quarters for parliamentary officers, temporary accommodation for the deputies, and the Royal Seat during the ruler's sojourn in Stettin (Gwiazdowska 2001, p. 194). From its western side, the frontage was closed by the Militärkaserne/Neue Baracke building, which was designed with a simple baroque form. The symbolic process of establishing the Prussian ruling 'space' in the city was concluded with the last investment project promoted by Frederick Wilhelm I, the rebuilding of the medieval facades of the Professors' Houses (Prediger- und Professorenhäuser) of the St. Mary's Foundation. The houses were also designed to imitate the Prussian baroque style (Gwiazdowska 2001, pp. 194-96; Fredrich 1920, p. 35) (Figure 2). 


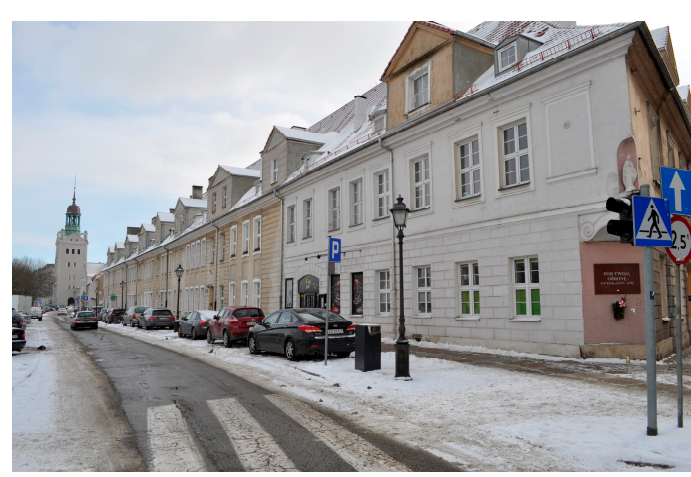

(a)

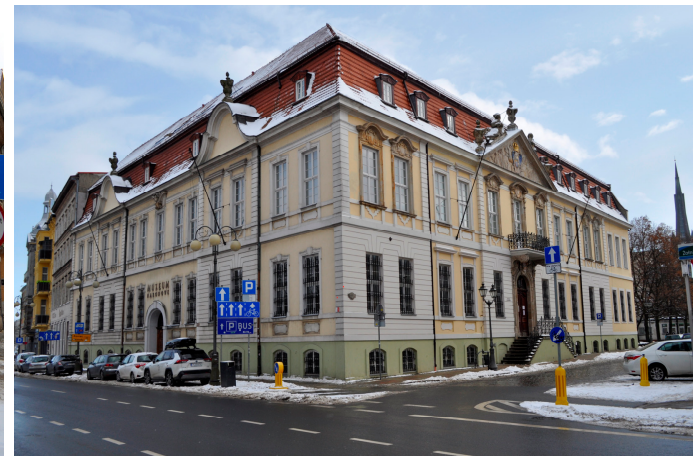

(b)

Figure 2. Prussian baroque in Szczecin, the buildings shown in both photos were funded by Frederick Wilhelm I. Their stylish forms and sculptural decoration emphasized the prestige and power of royal authority. Buildings of power (Table 2010. Znaniecki 1938): (a) Professors' Houses (source: created by author); (b) Pomeranian State Parliament (source: created by author).

In 1776, the Landwehr Zeughaus building was erected from the side of the square, near Peter's Bastion. Later, linden trees were planted in the square and 'discreet' Prussian emblems were added. One example of the latter is the first public monument to King Frederick the Great. The construction of the monument was perceived as an "expression of gratitude to Frederick the Great for his high opinion of Pomerania, the declaration of fidelity towards Prussia by Pomerania, as embodied by the most distinguished ruler, and the sense of unity with Prussia." The monument was also an expression of 'sentimental patriotism' and a 'means to build the myth and legend of the king' (Gwiazdowska 2001, p. 203; Balke 1929, p. 3). The foundation of the monument can also be perceived as a success story for Prussian propaganda, and as representation of the citizens of Stettin approving their political and economic ties with the Kingdom of Prussia. At the same time, due to the apt combination of green elements and a homogenous urban interior space, the square became a popular city area attracting 'crowds of elegant citizens' (Stẹpiński 1994, p. 235).

In the early 19th century, a new post office building was erected (Posthaus 1828, Ober Postamt 1843) in the vicinity of the demolished medieval Mühle Gate; in 1878 it was taken over by the military. In 1886-1889, the former post office was linked to the adjacent building, which since 1838 had been the official accommodation for the commander of the 2nd Army Corp (Berghaus 1876, p. 663). The two buildings were given a homogenous form and converted into the Military Headquarters (Kozłowska 1993; Borkowska 1977).

The formation of a class system in the first half of the 19th century resulted in facilities being established which performed new functions to meet the cultural aspirations of the bourgeois. These new functions included opera houses, theatres and museums. Stettin's merchant elites, who considered the building of a theatre essential, funded the building of the City Theatre. To highlight its location, it was situated on Königsplatz, at that time the only undeveloped spacious site in the city-a city that was surrounded by heavy fortifications. The theatre's official opening was combined with the unveiling of the Frederick Wilhelm III monument, situated in front of the theatre building. The architectural composition of the building, which was modelled on an unrealized design of a Berlin theatre by Friedrich Gilly, represented the city intelligentsia's neohumanist attitudes as expressed in its classical and Renaissance forms (Eopuch 1999, pp. 32-33, 47; Wehrmann 1911; Thiede 1849, p. 933). The simple, modest form of the building was distorted by a series of extensions which enlarged the building's usable surface area (vestibule, 1899, Franz Schwechten, ANB 5835, National Archives in Szczecin) (Figure 3). 


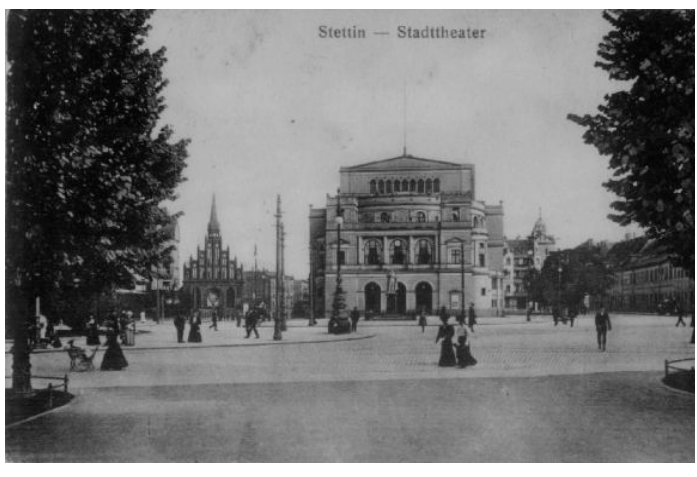

(a)

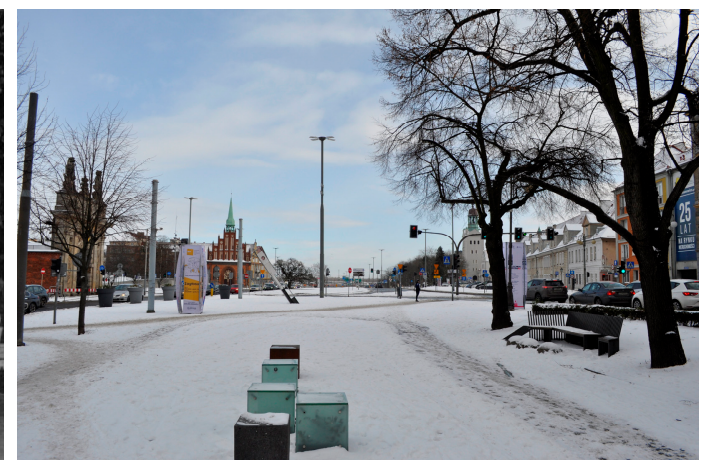

(b)

Figure 3. Plac Żołnierza Polskiego in Szczecin, both photos were taken from a similar perspective: (a) before 1939, the spatial dominant of plac Żołnierza Polskiego was City Theatre, shown in photo from the side of the front elevation. The theatre, a building of culture, should be interpreted as a product of the spatial practice of the new bourgeois-actor (source: sedina.pl); (b) nowadays, the square has the character of an open space; the former dominant (the theatre building) has been replaced by the road system of the Castle Route. In the foreground, elements of the small architecture of aleja Kwiatowa (source: created by author).

Another important event in the architectural and urban development of the city was the decision to demolish the fortifications, which was approved by the military authorities in 1873. The former fortifications were redesigned into residential quarters which followed a design concept by James Hobrecht, later modified by Konrad Kruhl (Kozińska 2002). North of the former line of ramparts, a system of residential quarters was developed with the so-called Berlin houses that are typical of the Stettin city center (1887, Am Königstor 1, ANB 2347, National Archives in Szczecin; 1906-1907, Königsplatz, 14 ANB 3715, National Archives in Szczecin). In the western part of the square, a monument to Emperor Wilhelm I was erected. The tradition of monuments which presented Roman emperors on a horse "manifested the emperor's majesty and authority and the imperial power of the emperor." This visible increase in the number of monuments that "conveyed ideology and political content' depicted "the historical process of politicising urban spaces" in the second half of the 19th century (Eopuch 1999, pp. 76-78). In the early 20th century, plac Żołnierza Polskiego was filled with architectural structures. In 1934-1935, the final undeveloped plot (the commander's garden in former Bastion IV) was developed with the construction of the Städtische Sparkasse Stettin building (City Saving Banks; later the Regional Committee of the Communist Party, the District Court, and a PKO SA Bank). The building featured a typical German architecture style with a brick façade. In 1941, the house adjacent to the bank was converted to the Haus des Gaupresse, and after the war into the Press House with the editorial offices of Głos Szczecinski, the then daily of the Communist Party, Kurier Szczecinski (the Kurier Szczeciński was a daily newspaper established in Szczecin in 1945), and the PAP (PAP_Polska Agencja Prasowa (Polish Press Agency)) (Piskorski 1960, p. 27).

In 1978, work began on developing the Castle Route, an overpass crossing the Oder River, in the free eastern section of the square. The plot had been previously occupied by the theatre building which had been demolished after the war. The first inbound section of the overpass opened in 1987, and in 1996 its outbound lanes were made operational (Sternicki 2000, pp. 540-41). The building of a multiple-lane bridge with wide exits had a negative impact on the aesthetics of the square.

After WWII, only a few buildings were constructed around plac Żołnierza Polskiego. In 1990, at the outlet of the Castle Route, a monument was established, the Mast of s/s Kapitan K. Maciejewicz, as a "symbol of the maritime nature of the city" (Kubowska 2017), whereas in 2011-2012, the square was modernised along aleja Kwiatowa (Flower Avenue). The project included a large sundial placed in front of the King's Gate, and a glazed pavilion 
for the Tourist Information Office on the side of ul. Niepodległości (Independence Street) (Sachanowicz 2012).

\section{- Plac Solidarności in Szczecin}

Plac Solidarności (Solidarity Square) was created after World War II on the site of a former perimeter block (which had been destroyed by Allied air-strikes), between ul. (Ul. = abbreviation of Pl. ulica, street). Małopolska (Augustastraße), plac Hołdu Pruskiego (Am Königstor), plac Żołnierza Polskiego (Königsplatz), and ul. Tadeusza Mazowieckiego (An St. Peter u. Paul). The square also contains the church of St. Peter and Paul, one of the oldest churches in the city (restored in 1901). In the second half of the 19th century, on ul. Małopolska (Augustastraße), the Konzert-und Vereinshaus was built: it was a venue for meetings and entertainment for the prewar city elite. The building was in the style of Wilhelmine baroque (a French classic baroque style, previously interpreted as mature Renaissance). Its form was monumental and its elevation richly articulated, creating a noble impression and highlighting the burgher tradition of Stettin (Eopuch 1999, pp. 74-75) (Figure 4).

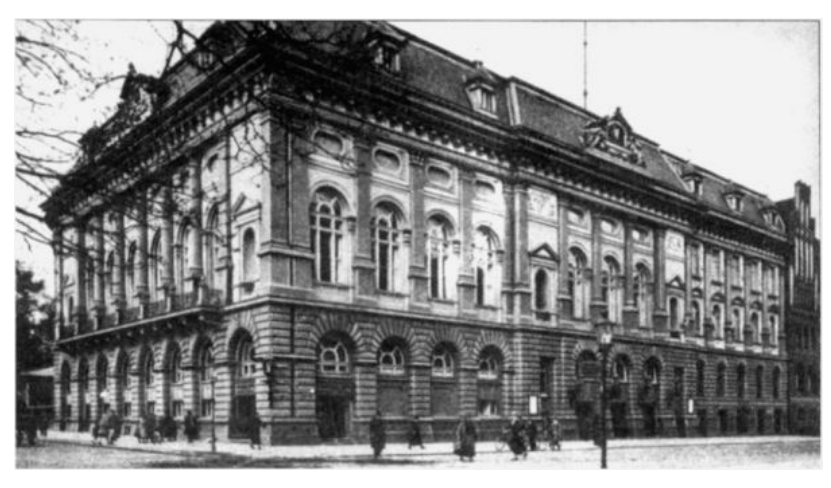

(a)

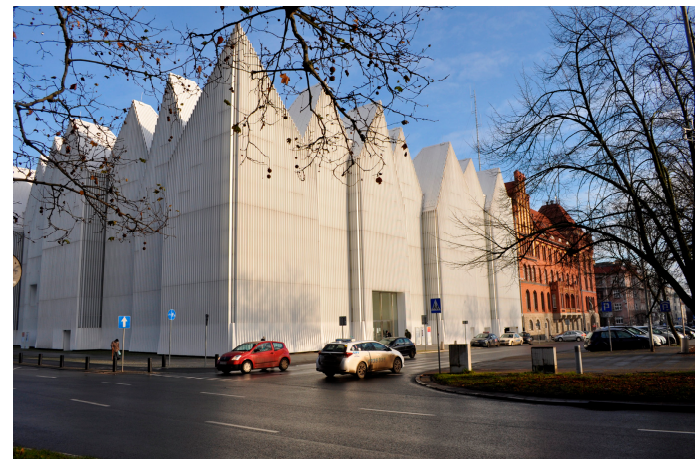

(b)

Figure 4. Plac Solidarności in Szczecin, with both photos taken from a similar perspective: (a) before 1939, Konzerthaus (source: sedina.pl); (b) today, the Mieczysław Karłowicz Philharmonic Orchestra House (source: created by author).

The Konzerthaus building was adjacent to the Royal Police Headquarters (Königliches Polizei-Präsidium). In the past, this building, which is now the Regional Police Headquarters, was the seat of the Militia Headquarters and the Regional Public Security Office from 1946. In 1956-1983, it was also occupied by the Security Service, and in 1983-1990, it housed the Regional Internal Affairs Office (Walkiewicz 2013). The building's exterior had a Gothic form, which in the reign of Wilhelm the Great was considered to be the German national style. From the side of St. Peter and Paul Square, spatially integrated with plac Solidarności, the Pomeranian House (Pommernhaus) was built in 1924 to the design of the distinguished architect Adolf Thesmacher. The building was used for office and retail purposes. It represented traditional modernist architecture, combining a reinforced concrete structure with brick façade cladding. Today, it is the seat of the Police Headquarters and the State Security Office (Łopuch 1999, p. 118).

After the war, the destroyed residential quarter was never rebuilt. In the 1960s, the square was occupied by a playground, which was removed in 1970. In the 1980s, the area served as a bus terminus.

On the 25th anniversary of the August Agreements, the Monument to the December 1970 Victims, commonly referred to as the Angel of Freedom, was unveiled. The monument commemorates the events of December 1970, including the riots in plac Solidarności and plac Żołnierza Polskiego, which led to the death of 16 people. In 2009-2013, the Dialogue Centre 'Upheavals' (DCU) was developed in the underground below the square as an exhibition space of the National Museum in Szczecin; this refers to key points in the history 
of Szczecin, such as the transfer of the city to Poland as a result of the Yalta Agreements, and the social protests of 1970, 1981, and 1989, which led to Poland regaining sovereignty in 1989 (Nekanda-Trepka 2017) (Figure 5).

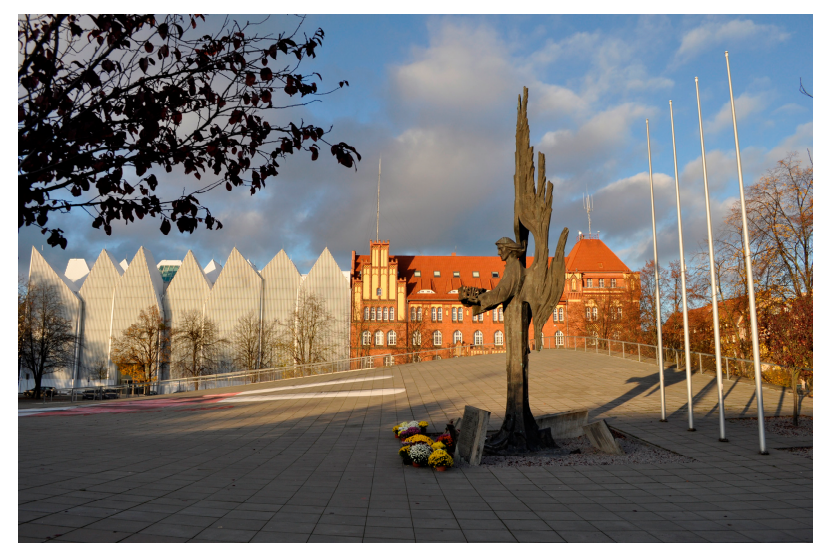

(a)

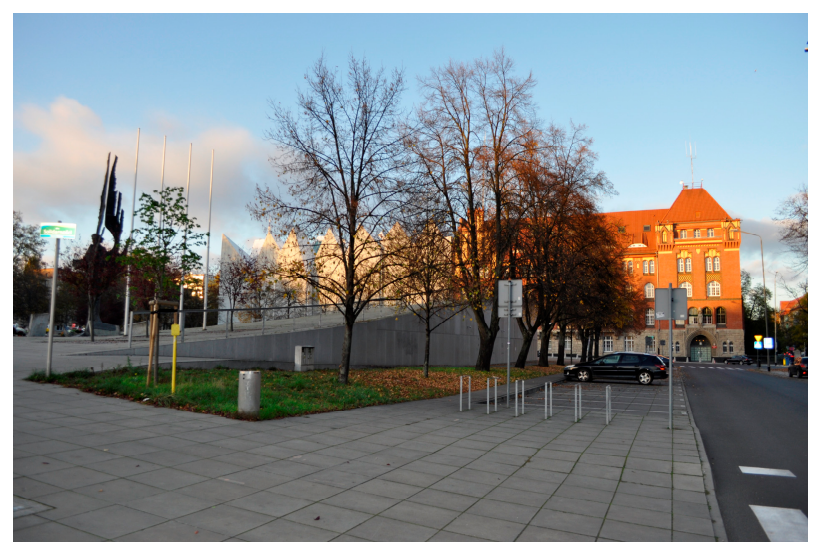

(b)

Figure 5. Plac Solidarności in Szczecin. The square was built on the site of a former residential quarter, which was demolished during World War II. As a place of workers' protests, it became a symbolic space-a place of lieux de mémoire, initiating the process of emancipation and of building the 'identity of the citizen of Szczecin': (a) Monument to the December 1970 Victims (source: created by author); (b) the Dialogue Centre 'Upheavals' (DCU), view from ul. Tadeusza Mazowieckiego (source: created by author).

The last component of the square was the Mieczysław Karłowicz Philharmonic Orchestra House, built in 2011-2014 on the site of the pre-war concert house. The philharmonic has an illuminated façade and roof. It has become a showpiece of development in the city; both architectural facilities have received many awards and mentions in architectural competitions (Nekanda-Trepka 2017), the most important of which are the 2014 Eurobuild Awards in the category of Architectural Design of the Year (available online: https: / / eumiesaward.com/edition/2015 (accessed on 1 November 2020)), the 2015 Mies van der Rohe Award, the EU Award for contemporary architecture, and the award to the DCU for the best public space in the European Prize for Urban Public Space 2016. (available online: https: / / www.publicspace.org/documents /220568/1852804/Premsa_Premi+01 6_ENG.pdf/237d6aa6--5f9b-871e-7e5e48838169d10e (accessed on 1 November 2020)).

The greater and lesser architecture objects discussed in the chapter 'Urban and formalsemiotic components' are listed in Table 1. The table contains information relating to the name of the building/monument, its date of construction, its date of reconstruction after WWII or its final demolition, its architect, style and function. The numbering assigned to each specific building in the table has been used in the analyses of the cultural landscape. The table and analyses of the urban landscape should be analyzed together. The table includes objects that do not exist in the present urban fabric but which are part of the historical and morphological analyses, showing the architectural and urban development of both squares. 
Table 1. The complex of architectural structures located on plac Żołnierza Polskiego and plac Solidarności in Szczecin, 1725-2020.

\begin{tabular}{|c|c|c|c|c|c|}
\hline No. & Building & $\begin{array}{c}\text { Data/Reconstruction } \\
\text { Demolition }^{-}\end{array}$ & Architect(s) & Style & Function \\
\hline 1 & \multicolumn{5}{|c|}{ Plac Żołnierza Polskiego } \\
\hline 2 & King's Gate & $1725-1727 / 1957^{\circ}$ & $\begin{array}{c}\text { Gerhard Cornelius } \\
\text { Walrave/Bartholome } \\
\text { Damart }\end{array}$ & Dutch baroque classicism & $\begin{array}{l}1994 \text { gallery / } 2000 \\
\text { café }\end{array}$ \\
\hline 3 & $\begin{array}{c}\text { Landeshaus/Pomeranian State } \\
\text { Parliament }\end{array}$ & $\begin{array}{c}1726-1727 / \\
1946^{\circ} 1740-1742 / \\
1964-1969\end{array}$ & $\begin{array}{c}\text { Gerhard Cornelius } \\
\text { Walrave/Bartholome } \\
\text { Damart }\end{array}$ & Prussian baroque & $\begin{array}{c}1726 \\
1926-1927 \text { museum }\end{array}$ \\
\hline 4 & Militärkaserne/Neue Baracke & $1727-1729 / 1903^{-}$ & - & Prussian baroque & military \\
\hline 5 & Professors' Houses & 1740-1742/1964-1969 & J.F. Freund & Prussian baroque & residential \\
\hline 6 & Landwehr Zeughaus & $1776 / 1902^{-}$ & - & - & military \\
\hline 7 & $\begin{array}{l}\text { Frederick the Great } \\
\text { monument }\end{array}$ & $1793 / 2008-2011^{\circ}$ & $\begin{array}{l}\text { Johann Gottfried } \\
\text { Schadow }\end{array}$ & Classicism & $\begin{array}{l}\text { landscape } \\
\text { architecture }\end{array}$ \\
\hline 8 & Military headquarters & $\begin{array}{c}1886-1889 / \\
1957-1958^{\circ} / \\
\text { palace } 1962-1965^{\circ} \\
1975-1980^{\circ} / \text { museum }\end{array}$ & - & Baroque classicism & $\begin{array}{l}\text { military/1958 culture } \\
1980 \text { museum }\end{array}$ \\
\hline 9 & City Theatre & $1846-1849 / 1954^{-}$ & $\begin{array}{l}\text { Carl Ferdinand } \\
\text { Langhaus }\end{array}$ & Classicism & culture \\
\hline 10 & $\begin{array}{l}\text { Frederick Wilhelm III } \\
\text { monument }\end{array}$ & $1849 / 1945^{-} / 2012^{\circ}$ & Friedrich Drake & Classicism & $\begin{array}{l}\text { landscape } \\
\text { architecture }\end{array}$ \\
\hline 11 & $\begin{array}{l}\text { Emperor Wilhelm I } \\
\text { monument }\end{array}$ & $1894 / 1945^{-}$ & Karl Hilger & Wilhelmine neobaroque & $\begin{array}{l}\text { landscape } \\
\text { architecture }\end{array}$ \\
\hline 12 & $\begin{array}{c}\text { Haus des Gaupresse/Regional } \\
\text { Press House }\end{array}$ & 1890-1941 & Gustav Gauss & Eclecticism/Neoclassicism & culture/office \\
\hline 13 & $\begin{array}{c}\text { Städtische Sparkasse } \\
\text { Stettin/City Savings Bank, } \\
\text { Regional Committee of the } \\
\text { Communist Party, District } \\
\text { Court, PKO SA Bank }\end{array}$ & 1933-35 & Gustav Gauss & Fascist architecture & $\begin{array}{c}1933 \text { bank/ } \\
1945 \text { office / } \\
1990 \text { bank, court }\end{array}$ \\
\hline 14 & $\begin{array}{l}\text { Mast of s/s Kapitan K. } \\
\text { Maciejezwicz, monument }\end{array}$ & $1990 / 2013^{-}$ & - & - & $\begin{array}{l}\text { landscape } \\
\text { architecture }\end{array}$ \\
\hline 15 & $\begin{array}{l}\text { Flower Avenue (Aleja } \\
\text { Kwiatowa) }\end{array}$ & 2011-2012 & Pracownia Studio A4 & - & $\begin{array}{l}\text { landscape } \\
\text { architecture }\end{array}$ \\
\hline 16 & & & Plac Solidarności & & \\
\hline 17 & Church of Sts Peter and Paul & $1223-1237 / 1425$ & - & Gothic style & church \\
\hline 18 & $\begin{array}{c}\text { Konzert-und Vereinshaus, } \\
\text { Konzerthaus }\end{array}$ & $1883-1884 / 1962^{-}$ & Franz Schwechten & Wilhelminian neobaroque & $\begin{array}{l}\text { culture, } \\
\text { gastronomy }\end{array}$ \\
\hline 19 & $\begin{array}{c}\text { Royal Police } \\
\text { Headquarters/Regional } \\
\text { Police Headquarters, Security } \\
\text { Service }\end{array}$ & 1902-1905 & & Gothic Revivalist & administration \\
\hline 20 & Pomeranian House & 1924 & & Modernism & trading house \\
\hline 21 & $\begin{array}{c}\text { Monument to the December } \\
1970 \text { Victims (Pomnik Ofiar } \\
\text { Grudnia 1970) }\end{array}$ & 2005 & & - & $\begin{array}{l}\text { landscape } \\
\text { architecture }\end{array}$ \\
\hline 22 & $\begin{array}{c}\text { Dialogue Centre 'Upheavals' } \\
\text { (DCU) (Centrum Dialogu } \\
\text { 'Przełomy' (CDP)) }\end{array}$ & 2009-2013 & & Conceptualism & museum \\
\hline 23 & $\begin{array}{c}\text { Mieczysław Karłowicz } \\
\text { Philharmonic Orchestra } \\
\text { House }\end{array}$ & 2011-2014 & & - & culture \\
\hline
\end{tabular}




\subsubsection{Features of the Spatial Structure}

Analyses of the internal (private and semi-public space) and external space (public space) of the structures of plac Żołnierza Polskiego and plac Solidarności show their transformations and development through the period 1725-2020, distinguishing five stages. Column ' $a$ ' presents the system of public spaces, streets and squares (external spaceconvex), while column ' $b$ ' lists the development systems of these squares with the urban blocks surrounding them (external space-concave). There is a relationship of mutual complementarity of space between both systems, which at the same time shows the proportions between built-up space and open space (Paszkowski 2008). The analyses of the urban structure should be considered together with the analyses of the urban landscape and Table 1.

When analyzing the network of streets and squares (column 'a') from phase I and II, it appears that plac Żołnierza Polskiego, which was built on the site of a medieval moat and city walls (Kozłowska 2007), was the largest public space in Szczecin, next to aleja Niepodległości (Independence Avenue), founded at the same time. Both squares were characterized by a longitudinal layout resulting from conditions related to the existing urban fabric on the one hand, and on the other to the modern fortifications, which were expanded at that time by the new Prussian authorities. When compared to the medieval city squares (Rynek Sienny, the largest market in Szczecin had an area of c. 0.59 ha), plac Żołnierza Polskiego, with dimensions of c. $55 \times 430 \mathrm{~m}$ and an area of c. 2.37 ha, was a modern, monumental space, and thus became a natural choice for the location of the buildings of government. A road led to the square from the foreground of the fortress. The construction of the City Theatre (column ' $a$ ', phase II) did not significantly affect the layout of the square. The building was 'squeezed' in the eastern part of the square, with the northern facade being adjoined to the embankments of early modern fortifications. An important change in the square's external structure took place after the decision to de-fortify the Szczecin fortress in 1873, and the adoption of a plan to develop the post-fortress site in 1876 (Kozłowska 2007; Kozińska 2002), which is illustrated by the drawing: column ' $a$ ', phase III. In the northern part of the complex, the street network was characterized by a regular layout of wide streets, in opposition to the irregular arrangement of narrow streets in the medieval part of the city (the southern part of the square). On the west side of the square there is a three-axis system, while a regular form of street interior was created around the City Theatre using a trapezoidal layout. The area of the square was also increased (to c. 3.39 ha) as a result of the partial occupation of the former embankments of the early modern fortifications. This system was redefined as a result of World War II. In 1945, the process of rebuilding the city structure of plac Żołnierza Polskiego began. The street layout on the south side was preserved, while on the northern part, aleja Niepodległości (column 'a'-phase IV) was widened, and an open space was established on the site of the former urban block (the future plac Solidarności). The network of streets located in the eastern part of the square was also liquidated, and the Castle Route was built in its place (Musekamp 2015).

An analysis of the system of the square's development is presented in column ' $b$ '. The research showed that in the first and second phase, the square on the south side was surrounded by medieval urban blocks of irregular forms. The northern part of plac Żołnierza Polskiego was devoid of buildings, and in their place were the earth and brick embankments of the early modern fortifications (Kozłowska 2007). The system discussed was changed in the third phase, as a result of the erection of perimeter blocks in the northern part of the square, which had regular quadrilateral forms and parameters comparable to medieval urban blocks in the southern part of the square (Kozińska 2002). Phase IV illustrates the lack of a perimeter block on the site of the present plac Solidarności, as well as the development of the eastern part of the square with the former City Theatre, which has been replaced by an extensive system of road communication (the Castle Route, Trasa Zamkowa). In phase $\mathrm{V}$, the perimeter block is supplemented in the northern part of the 
square by the construction of the philharmonic complex and the topographic construction of the museum by plac Solidarności, which is the public face of the square.

The third phase of the development of urban structure is characterized by the greatest extent of the spatial system's crystallization. A high degree of spatial disintegration (open system) presents phase IV of the development of the structure of plac Żołnierza Polskiego, which resulted in the negative image of the spatial effects. Phase V portrays the crystallization of the spatial system (Figure 6).
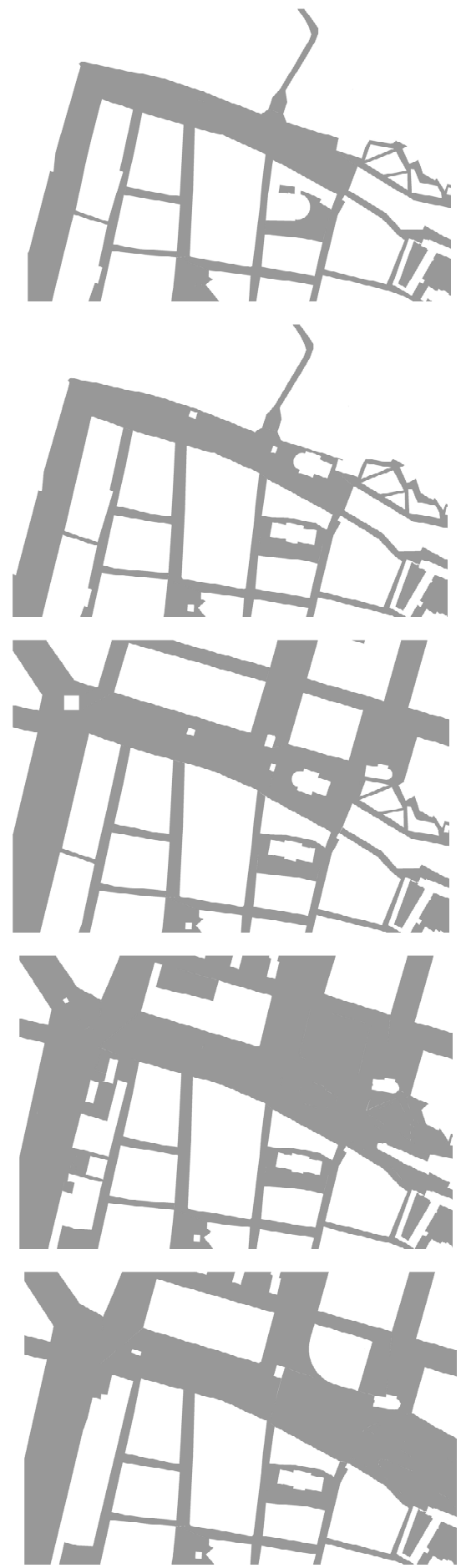

(a)

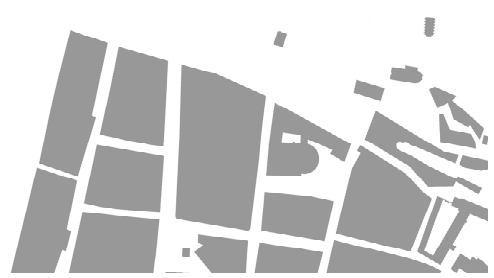

Phase I

$1750-1849$

Phase II
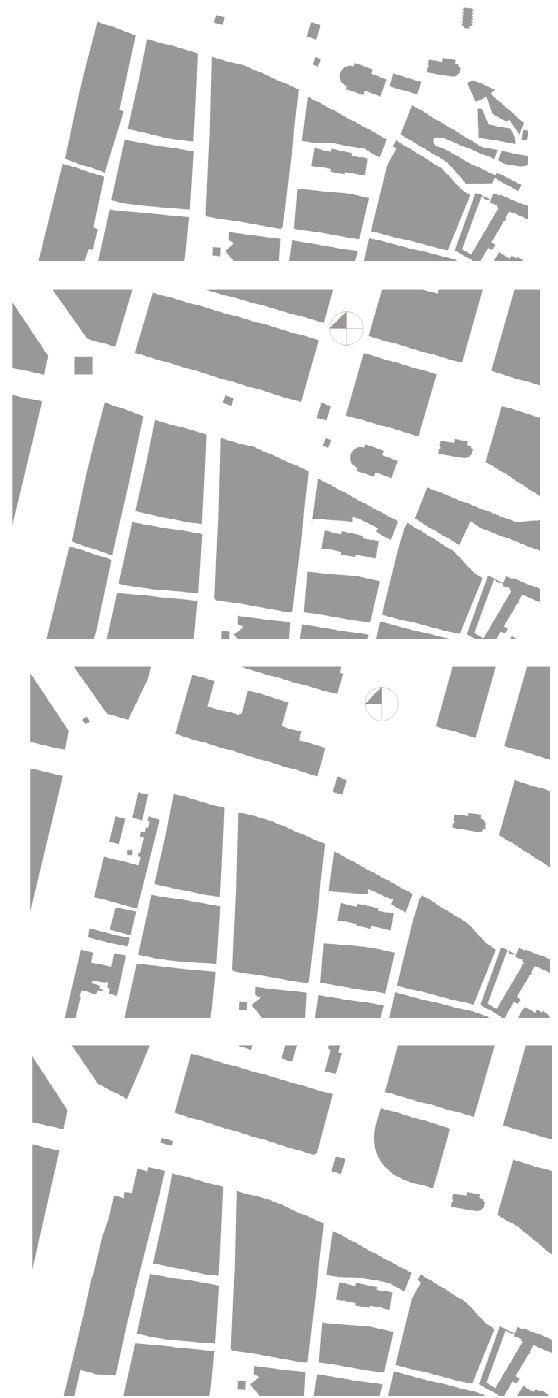

(b)

Figure 6. The process of changes in the space of plac Żołnierza Polskiego and plac Solidarności in Szczecin. The division of the spatial structure of the city: (a) convex structure (source: created by author I. Kozłowska); (b) concave structure (source: created by author). 


\subsection{Reading the Spaces of Dependence and Emancipation}

3.3.1. Baroque Architecture as a Tool of Royal Policy to Create Identification with the Prussian State: Spaces of State Dependence

Most of the historic morphological elements of plac Żołnierza Polskiego were created just after the Prussian government took over the town in 1713. The construction of a Prussian fortification around the existing Swedish fortress resulted in the residents being even more tightly enclosed within the urban space (Kozłowska 2007). The experience of oppression was accompanied by the cultural process of colonizing the urban space, which had hitherto displayed the typical elements of a medieval Hanseatic city. Analyses have revealed the presence of some representative buildings, i.e., 'buildings of power' (the Senate building = the residence of the ruler; the barracks, the building of the military headquarters), along the fortifications' northern line (Figure 7).

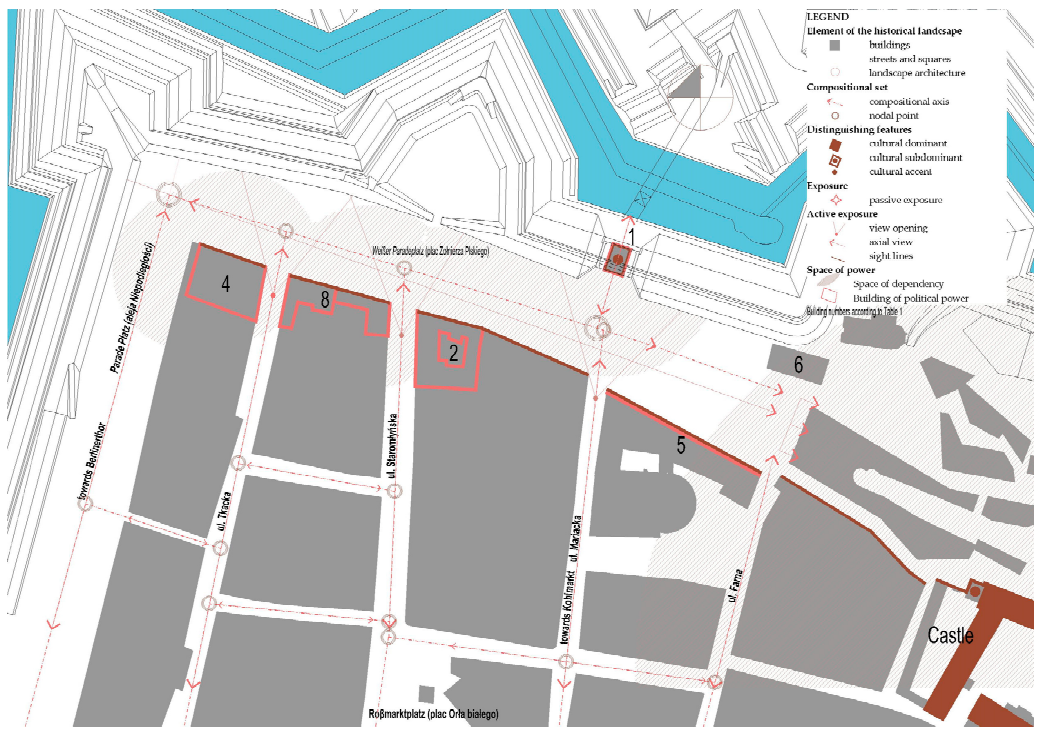

Figure 7. Landscape analysis of plac Żołnierza Polskiego in 1750. Plac Żołnierza Polskiego was located between the northern line of the modern fortifications and the medieval perimeter blocks which form a sight line. The main compositional axis of the complex stretched along an east-west line, at the same time creating an axial view. In the western part of the square, the axis formed a nodal point with the main axis of the composition of plac Niepodległości. From the east, the square had a view onto the Oder valley. The dominant form of the square was the space of authority, including the buildings of the royal administration, state authority and military authority $(1,2,4,8)$. The main entrance to the city led through the King's Gate (1), a subdominant located on the axis of ul. Mariacka. As a symbol of royal rule and domination over the city, the Gate was equipped with rich, symbolic sculptural decorations. The dominant feature in the northern spatial structure of Szczecin was the Pomeranian Duces' Castle, with an accent in the form of the Bell Tower (source: created by author).

The architecture in the square was given a uniform Dutch baroque style, with two-story buildings covered by mansard roofs. The creation of a homogeneous architectural structure resulted in a compact urban environment with a static, calm form (Słomiński et al. 2000; Słomiński 1987). The balanced layout of the walls gave the impression of "a uniform urban complex" (Wejchert 1984), focusing on the architectural detail of the Landeshaus and the Königstor (King's Gate). The square expanded eastward, with a narrow gap and a moat at one end, opening into the Oder river valley. The medieval streets of the old town sent a stream of traffic toward plac Żołnierza Polskiego, and further toward the King's Gate, a structure of sophisticated form and features emphasizing the prestige of the ruler (Słomiński 1987). In this built-up area, the Tower of the Pomeranian Dukes' Castle marked the space to the east. The castle itself was converted into offices for the Prussian government, with royal chambers in the northern wing and the headquarters of the fortress commander in the western wing (Kroman 1992). 
The second modern square, the current plac Niepodległości (Independence Square), created at a similar time to plac Żołnierza Polskiego, did not attain such social and political significance. This urban space, deprived of public utility functions, only featured the representative Port Gate (Berliner Tor). It was designed and decorated by the same creators who developed the King's Gate (Kozłowska 2007; Słomiński 1987). The broad Breite Straße (now ul. Księdza Kardynała Stefana Wyszyńskiego) led from the gate, which was the main traffic route toward the quay (Paszkowski 2008). The lesser importance of Independence Square is also demonstrated by the lack of any wide streets running from the side of the Old Town.

Analyses have shown that, in terms of the overall structure of the city, plac Żołnierza Polskiego was a royal space with buildings in the new architectural style, thus creating a unique, homogenous urban zone. The royal investments in the square bear the hallmarks of activities deliberately aimed at building an emotional bond with a ruler who was new to Stettin, in order to create a Prussian identity for its inhabitants.

\subsubsection{Neohumanism as a Vehicle for Bourgeois Ideas in Plac Żołnierza Polskiego}

In 1849, the square was significantly transformed by the building of a theatre, a facility meant to fulfil new social needs (Łopuch 1999). The opening of the City Theatre changed the urban layout of the square along its eastern side, and transformed it into an urban interior with a landmark development. Smaller integrated urban interiors developed around the theatre. The theatre building and the residential buildings erected along the former gap near the castle obstructed the view of the Oder Valley panorama. The square had lines of trees planted along it, and became more like a green avenue. The change was not only material in nature; the foundation of the theatre represented a form of cultural emancipation for Stettin's bourgeoisie at the time. Many iconographic and literary works show the change in spatial practices that took place within the area of the square (Gwiazdowska 2001). Military drills and parades were replaced by the recreational practices of the rich bourgeois (Figure 8).

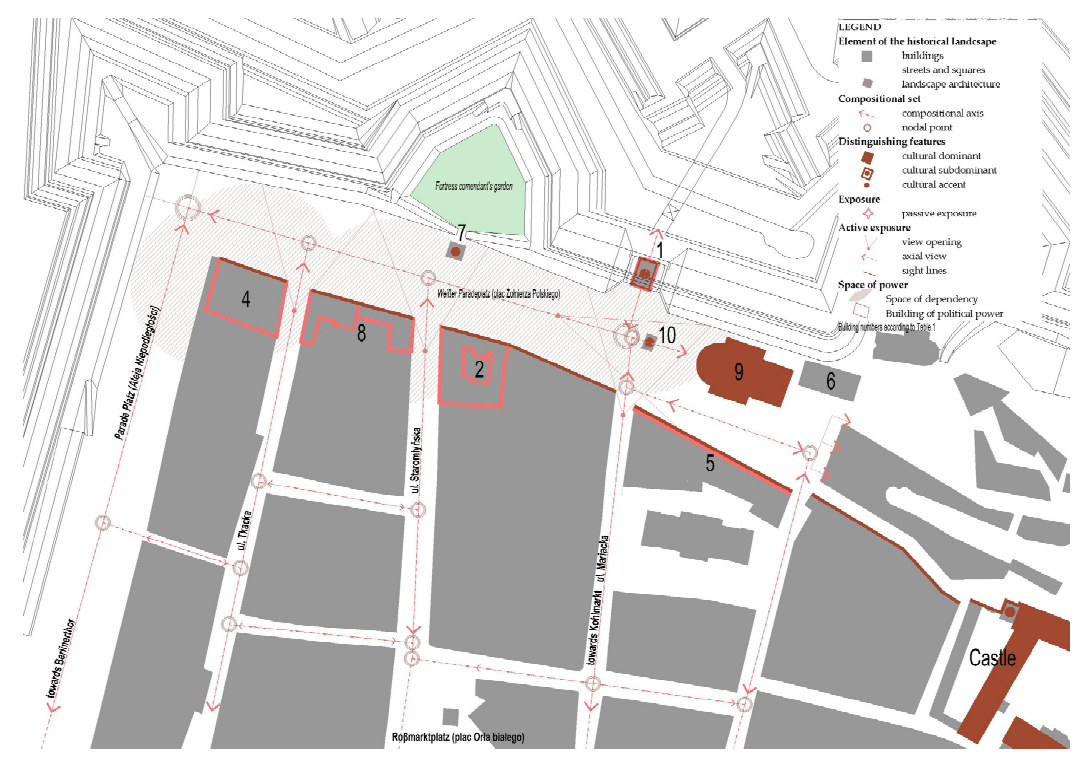

Figure 8. Landscape analysis of plac Żołnierza Polskiego in 1850. The main composition of the square's interior has not changed, as seen when compared to the illustration in Figure 7. The space of the square was supplemented with symbols and signs (7,10-royal monuments) emphasizing its representative and servile function in relation to the ruler. In the eastern part of plac Żołnierza Polskiego, the City Theatre (9) was erected, which became the spatial dominant of this interior. This building, located at the widest point of the square, adjoined the northern elevation to the fortress ramparts. The theatre was erected on the main axis of the square (source: created by author). 
Nevertheless, urban life continued within the limitations of the modern fortifications. The worsening living conditions, epidemics in the city, overpopulation, and the lack of space for economic and industrial growth led to a crisis (the Springtime of Nations) (Kozińska 2002). A breakthrough event for Stettin's residents was the decision to demolish the fortifications in 1873 . The city was given a chance to promote its urban, economic, and industrial development (Kozłowska 2007).

\subsubsection{The Politicization of Stettin's Urban Space at the Turn of the 20th Century}

Residential quarters were developed on plac Żołnierza Polskiego from its northern side, with a number of culture and retail facilities as well as restaurants. The city center's new urban structure, surrounding the square from the side of the former ramparts, was linked logically to the historical spatial arrangement. The natural funnel-like extension of the square was used to compose the interior in the shape of a rectangular trapezoid, a layout typical of iconic urban solutions (such as the Capitoline Square in Rome and St. Mark's Square in Venice) (Tołwiński 1948), to highlight the building of the City Theatre (Figure 9).

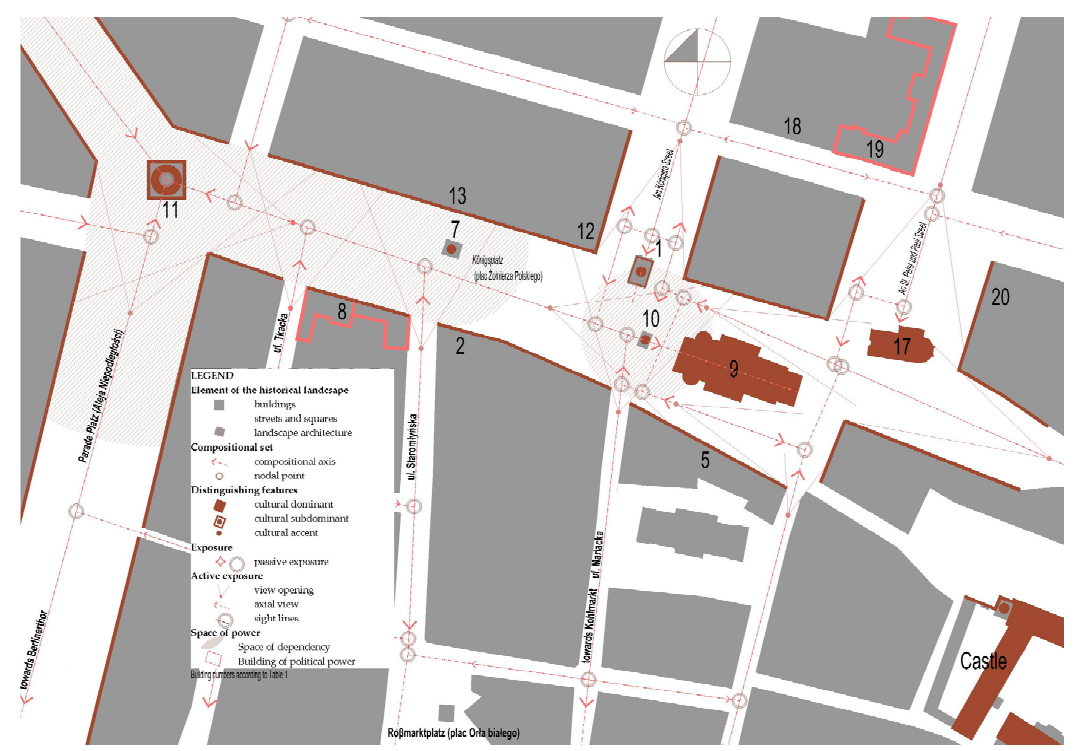

Figure 9. Landscape analysis of plac Żołnierza Polskiego in 1939. The main urban dominant of the square was the City Theatre (9), around which a complex system of urban interiors was composed with a complicated layout of nodal points, compositional axes, axial views and view openings. The space around the theatre was shaped like a trapezoid, with its arms widening to the east. The structure of the square on the northern side was laid out on the levelled modern fortifications in the form of regular perimeter blocks. At the stage of the spatial structure's development, the view of the Oder in the eastern part of the square was closed off. The nodal point of plac Żołnierza Polskiego and plac Niepodległości became the canvas for the three-axis street layout. This point was additionally strengthened by the location of a monument symbolic of imperial power (11) (source: created by author).

Adjacent to plac Żołnierza Polskiego was Am Königstor (plac Hołdu Pruskiego), a space displaying a baroque monument, a relic of Stettin's old fortifications. A three-axis street layout (trident) was planned for the western side of the interior. In the Baroque period, similar urban developments based on multiple axes symbolised an absolutist order (such as Versailles) (Tołwiński 1948). In the case of the square, these connotations were evoked by the construction of an equine monument of Emperor Wilhelm I. The strong political tone of this area was counterbalanced by numerous cultural and service facilities.

The square, together with its immediate surroundings, became one of Stettin's most important urban areas at that time, with its 'strong imprint' of turn-of-the-20th-century 
Prussian architecture (Konzerthaus, Pomerania House). One particularly popular motif of this architectural style was the brick facade and the Gothic-style details, which were recognized as the German Empire's national style. It was also used to encode 'new political, social and moral messages.' Apart from references to the tradition of Cologne cathedral (completed in 1880 and financed by the Prussian State), the neo-Gothic Prussian architecture referred to the indigenous northern European Gothic of Hanseatic cities (Łopuch 1999, p. 58). The multitude of neo-Gothic public facilities erected in the German Empire contributed to a specific Prussian cultural landscape designed to strengthen the social identity of its inhabitants (Musekamp 2015, p. 261). The politicized Prussian cultural space of Stettin, in its post-war reality and among its new users, was subject to various processes resulting from different strategies that rejected, accepted, modified or reformulated such elements (Musekamp 2015, p. 35).

This research has enabled a historical and cultural decoding of the virtual and real spaces (Schlögel 2016) in the German city of Stettin, as well as an understanding of the processes which resulted in the adoption of certain strategies and architectural and urban activity after 1945 .

\subsubsection{After 1945: Building Szczecin's Polish Identity}

In 1945, following a political decision, Szczecin (Stettin) and the 'Recovered Territories'-Lower and Opolian Silesia, Western Pomerania and the Warmia-Masuria Province-became Polish. In the new geopolitical reality, Poland became a socialist state allied with the Soviet Union, and fell under its ideological and political influence.

The reconstruction of Polish Szczecin was subject to ideological rules aimed at "building the foundations of socialism in Poland" (Grzelak 2013). The 'struggle' for socialist architecture rejected "sterile ... bourgeois eclecticism and neo-romantic decorative elements" (Borkowski 1950, p. 3). Inspirations for the reconstruction of the destroyed urban structures also came from international trends in architecture and urban planning, including the so-called Athens Charter of 1933, which referred to the creation of a rational, healthy living space in accordance with the slogan of 'Sun, Space, and Green' (Corbusier 2017).

The development of plac Żołnierza Polskiego, which had largely been destroyed during World War II, changed its architectural and urban structure. Ideological 'contempt' for traditional blocks resulted in decisions not to rebuild the destroyed residential buildings. As a result of the decisions, plots on plac Żołnierza Polskiego were left empty, as with plac Solidarności, which for many years was merely an unnamed green space. Plac Żołnierza Polskiego, which had a compact urban interior before the war, became an open urban interior (Figure 10).

In parallel with the reconstruction, other strategies adopted in Szczecin included the reconstruction or rebuilding of its architectural and urban structure, which depended on "the planned development of the city, its designation, traffic solutions, economic growth and the role of the city in the region and in the country" (Podlewski 1948, p. 110). All of these measures were therefore subordinated to the five-year economic plans of the Polish People's Republic. Once the hierarchy was defined, the key questions were: what should we rebuild, and how should we rebuild it?

The general negation of the Prussian architecture of the 19th and 20th centuries among Polish architects, urban planners, and conservators can be attributed to the conviction that it was alien in nature, overly prevalent in the 'Recovered Territories', and seen as a deliberate ploy to Germanise formerly Slavic lands (Zaremba 1980; Rewski 1949; Zachwatowicz 1948; Kajzerek 1946). Other accusations were based on aesthetic grounds, describing the architecture as "an orgy of ugliness and bad taste." (Rewski 1949) According to Poles at that time, the widespread use of factory-pressed bricks or clinker cladding was thought to have created "huge rough red or yellowish planes which disturb people, especially those who are more sensitive to colour" in cities (Rewski 1949). However, calls to minimise the influence of the Prussian architecture proved rather ineffective. The public buildings, modern in terms of their design and the materials used, turned out to be durable, robust, and highly 
adaptive. Hence, they are represented in larger numbers in the area of plac Żołnierza Polskiego and plac Solidarności after 1945 (the Royal Police Headquarters, Pomeranian House, and the Städtische Sparkasse Stettin). However, despite retaining their functional or spatial value, those Prussian buildings which had undergone a significant degree of deterioration were demolished. The situation was more complicated in Szczecin, since the demolished buildings of the Konzert- und Vereinshaus and the City Theatre were adjacent to the Security Service's office (Stużby Bezpieczeństwa) in the former building of the Royal Police Headquarters. An attempt to rebuild the Philharmonic Orchestra House was made in the 1960s, but was not approved by the Security Service (Musekamp 2015, p. 274). In the end, both buildings were demolished, and the interior of the square became a space which displayed little clarity. In literal terms, as an urban layout and as a social space, it had been disintegrated.

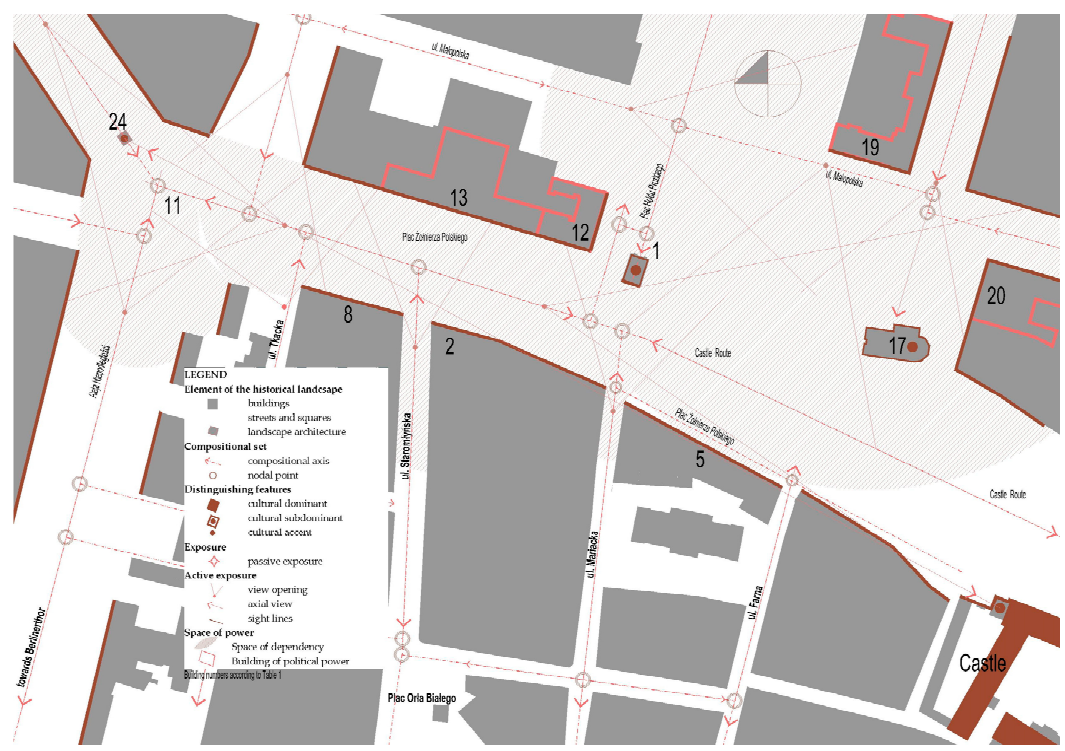

Figure 10. Landscape analysis of plac Żołnierza Polskiego in 1989. After the Second World War, the spatial arrangement of the square was decomposed. As a result, the main axis of the square's composition was shortened. The triaxial foundation was also corrected by removing the symbolic monument (11). It was replaced with a monument of dependence (Monument of Gratitude to the Soviet Army-24), which was situated on the central axis of the complex and visually connected with the accent- the tower of the ducal castle. There was a spatial connection between the two symbols of the state's historical policy. However, the main change in the space of plac Żołnierza Polskiego was the demolition of its main dominant, i.e., the building of the City Theatre. It was also decided not to rebuild the urban block, which formerly bordered on the theatre building from the north. In this way, an undefined and unnamed square (the future plac Solidarności) was created, and assigned various functions over time, such as a playground, a green square, and a public transport hub. On the northern side of both urban interiors, the buildings of ideological power were located, which were politically dependent on the Soviet sovereign $(12,13,19)$. The southern part of the square, formerly associated with the Prussian space of power, was transformed by giving it a new cultural function $(2,8)$. The extensive communication system of the Castle Route was constructed along the main compositional axis of plac Żołnierza Polskiego. The square had the character of an open urban interior with little legibility, where view openings dominated the closures of space (source: created by author).

It should be noted that all the baroque facilities erected in the first half of the 18th century on plac Żołnierza Polskiego were rebuilt. The 18th-century buildings were a political tool to consolidate Prussian rule in Pomerania (the Professors' Houses, the Landeshaus, the King's Gate, the military command headquarters). This can be explained by the interpretation adopted by Communist decision-makers that baroque architecture was 'pre-Prussian' 
with "artistic and cultural value," as well as a 'cosmopolitan form,' which was politically outdated, and thus not a threat to the ideals shared by the State (Rewski 1949).

The 'cultural continuity' of Szczecin, a city with centuries of German history and culture behind it, was broken with the transfers of populations after 1945. The new inhabitants of the city, a city which retained a clear German identity despite its war damage, started to take control of it. A process of harnessing the urban landscape and "re-coding its architectural and urban structure" was initiated (Przybył-Sadowska et al. 2016, p. 87). The first step was to "erase the German top layer" (Musekamp 2015, p. 36) ("wiping off the German layer," Zachwatowicz 1948), including German-language inscriptions and street names. The Szczecin Street Naming Commission, which in post-war circumstances inevitably followed political criteria, named one of the squares in honor of Stalin (it is currently named plac Odrodzenia, or Rebirth Square). The changes to street names progressed subject to the propaganda myths of the 'Recovered Territories' and the creativity of the Commission's members. Examples of the evolution of selected street names are given below:

- $\quad 1740$, White Parade Square/Weißer Paradeplatz; 1793, Königsplplatz; mid-1850s to 1945, Theaterplatz (the square's eastern part); 1945, plac Teatralny (Theatre Square); 1947, plac Żołnierza Polskiego (the Square of the Polish Soldier).

- 1725, Anklamer Thor; 1840, Königstor; 1945, Brama Hołdu Pruskiego (the Gate of Prussian Homage); 1950s, Brama Piastów / Brama Królewska (Piasts' Gate/King's Gate).

According to the Commission, "the names of streets in a socialist city should have an educational and motivational character" (Musekamp 2015, pp. 233-43). On this basis, the name of 'the Polish Soldier' (Żołnierza Polskiego) was intended to commemorate the wartime struggle of Polish soldiers, whereas the 'Gate of Prussian Homage' (plac Hołdu Pruskiego) referred to a historical event, namely the homage paid by the last Grand Master of the Teutonic Knights, Albrecht Hohenzollern, to the Polish King Sigismund I the Old in 1525 (Musekamp 2015). The same process was applied to the names of the buildings located on the square, such as the King's Gate, which was initially called Brama Piastów (the Piasts' Gate) to link the history of Szczecin with medieval Poland (the Piasts being Poland's first documented ruling clan) (Piskorski 1960).

Another group of constructions subject to the process of 'erasing the German top layer' included monuments. Their demolition and replacement with new symbols served to integrate Szczecin with Polish identity. The statue of Wilhelm I, the creator of the German Empire, which dominated the western part of the square, was removed on the last day of July 1945. Its remains were donated to Warsaw to make a copy of the monument to Prince Józef Poniatowski which German occupiers had destroyed during the war (Musekamp 2015, pp. 204-6; Ptaszyński 2009).

The intensity of the Prussian cultural landscape meant that simply changing toponyms or forms of signs could be considered insufficient in terms of altering the public's perception of them. An article in 1949 stated: "Despite their admiration of the beauty of nature and monuments, the Polish population of the 'Recovered Territories' and tourists feel that these areas are somehow alien to them" (Rewski 1949). The authorities responded to this perception of space in terms of differences and subordination, by 'making up traditions' to absorb the foreign cultural space (Hobsbawm 2008). New myths and cults referred to the shift of the Polish borders by speaking of a 'return to the Polish lands,' 'the recovery of the old Piast lands,' and 'a return to the Homeland,' and linking a local family of princes, the House of Griffin (Ger. Greifen, Pol. Gryfici), with the Piasts, the first Polish dynasty. "Central and local authorities developed a comprehensive socio-political programme to quickly create a sense of local patriotism" (Musekamp 2015, p. 35) by using various propaganda tools, such as fictional literature and scientific historical publications which 'traced' Polish periods in the history of the city and the region, as well as periodicals, new monuments, and architecture and urban development.

In the 1950s, plac Żołnierza Polskiego gained a new spatial and political framework. It was 'squeezed' between a symbol of the policy of dependency, namely the of the Soviet 
Army Monument (1950), and a symbol of the 'invented tradition', the Castle of Pomeranian Dukes. In the space of dependence, the monument became a socially unwanted, unaccepted form or sign (despite official celebrations being organized there), and also became a place to express disagreement (anti-Communist inscriptions appeared on the monument). However, the castle (reconstructed in 1958-1980), perceived as the emblem of the presumed Polish character of the native House of Griffin, proved to be a success story in the 'policy of regionalism' (Musekamp 2015, pp. 208-9), and survived the transformation after 1989.

However, these ideological and political actions did not become a spiritus movens for building a true identity of Szczecin.

\subsubsection{December 1970: The Development of Szczecin's Polish Identity}

The strikes and protests of December 1970 were crucial events in the development of Szczecin's Polish identity (Krasucki 2017). The area around plac Żołnierza Polskiego and what is now plac Solidarności became the scenes of anti-Communist protests organized by workers from the Adolf Warski Shipyard and thousands of their supporters. Here, too, force was used by the military and the police, and firearms were used on the demonstrators. The square became the birthplace of a myth soaked in struggle and sacrifice. The perspectives were reversed, and the city witnessed a shift from a space of dependence where "human phantoms swarm" (Raszka 1981, p. 48) into a space of emancipation. "People became proud to say that they were citizens of Szczecin, and the city itself was finally rooted in the Polish mental map" (Kowalewski et al. 2010).

The events of December 1970, strengthened by a further anti-Communist uprising in December 1980, initiated a social upheaval that 50 years later resulted in the transformation of plac Solidarności into a space of emancipation.

The square and the green area adjacent to it (today's plac Solidarności) was the location of the main institutions of the Communist government: the Security Service, the Regional Committee of the Communist Party, and Głos Szczecinski, the party's daily newspaper. The accumulation of authority in a single location acted like the fuse on a bomb. Additionally, the deformed structure of the square with its sociofugal space (Hall 1969, p. 108) provoked noticeable discomfort, which in emergency situations stimulated anger, hostility and aggression (Bańka 2009).

The decomposition of the square ended with the building of the Castle Route. This road, with its elaborate traffic structure, had a negative impact not only on the urban structure but also on the architectural nature of the neighboring historical district. The multilane road, planned in the former location of the City Theatre, subdivided the square and cut it off from today's plac Solidarności. Despite protests from architects and urban planners, the government pressed ahead (Musekamp 2015), perhaps to deliberately eliminate the lieux de mémoire, or remembrance sites, linked with the events of December 1970. This action was complemented by constructing a bus terminus next to the former Security Service Office.

\subsubsection{Szczecin's Space of Emancipation after 1989}

The year 1989 initiated a systemic transformation in Poland as a result of the collapse of the Soviet Union. Despite the 'break-up point', the "transition from a statecontrolled city to a city of citizens" turned out to be a long-term and multistage process (Wierzejska 2014, pp. 416-17). The urban and architectural structure of the two squares has long operated within the framework planned in 1945-1989. The first stage in transformation of square into a space of emancipation was the placement of the Maciejewicz mast between the inbound and outbound routes of the Castle Route to fill the void previously occupied by the City Theatre at the opening of the view to the Oder River. The monument referred to Szczecin's maritime character, which had already been promoted in the previous political system. Since it was essential for the public to commemorate the victims of December 1970, the development of the Freedom Angel monument was very important. The building of the monument was an initiative of the local council and the December 1970-January 1971 Association. It was preceded by two architectural competitions and a heated public and 
media discussion regarding its form and location (Musekamp 2015, pp. 370-74). The option of setting up the monument in a square prevailed-a square which since then has been officially named 'Solidarity Square'. This space has become an important site of memory, which initiated the process of creating Szczecin's post-dependence identity. The first stage of the space's emancipation ended with the modernization of plac Żołnierza Polskiego along the so-called 'Flower Avenue.' However, the introduction of monuments and 'small' architecture into the degraded urban space did not lead to the consolidation of this urban area. Moreover, the design measures adopted at this stage were unsatisfactory.

The buildings of the previous system, now abandoned by their users, changed their functions. The options for adapting the buildings representing Prussian architecture were re-opened.

The second stage in creating a civil city was focused on plac Solidarności. Plac Żołnierza Polskiego was transformed into an interior for traffic organization which mainly served to regulate the traffic flow (Wejchert 1984). The domination of motor traffic over the area's function as a city square has stigmatised the space, and restoring it to its former function would require the transformation of the city's transportation structure within the Old Town and city center. The year 1989 initiated the process of dislocation; Solidarity Square began to take over the function of plac Żołnierza Polskiego as the city center.

The shift was strengthened by the new facilities built on plac Solidarności, such as the new Philharmonic Orchestra House and the Pavilion of the Dialogue Centre 'Upheavals' (DCU). These two constructions were created as a result of bottom-up initiatives (the Public Committee for the Construction of the New Philharmonic House was set up in 2004). The establishment of the DCU in 2005 was initiated by a broad public discussion, involving intellectuals and politicians, focused on the role of Szczecin in the history of the social uprisings of the 1970s and 1980s. The new buildings, made according to designs selected in international architectural competitions, have become city icons and spaces where social needs (education, recreation, culture, and promotion) can be met (Rek-Lipczyńska and Kozłowska 2019) (Figure 11).

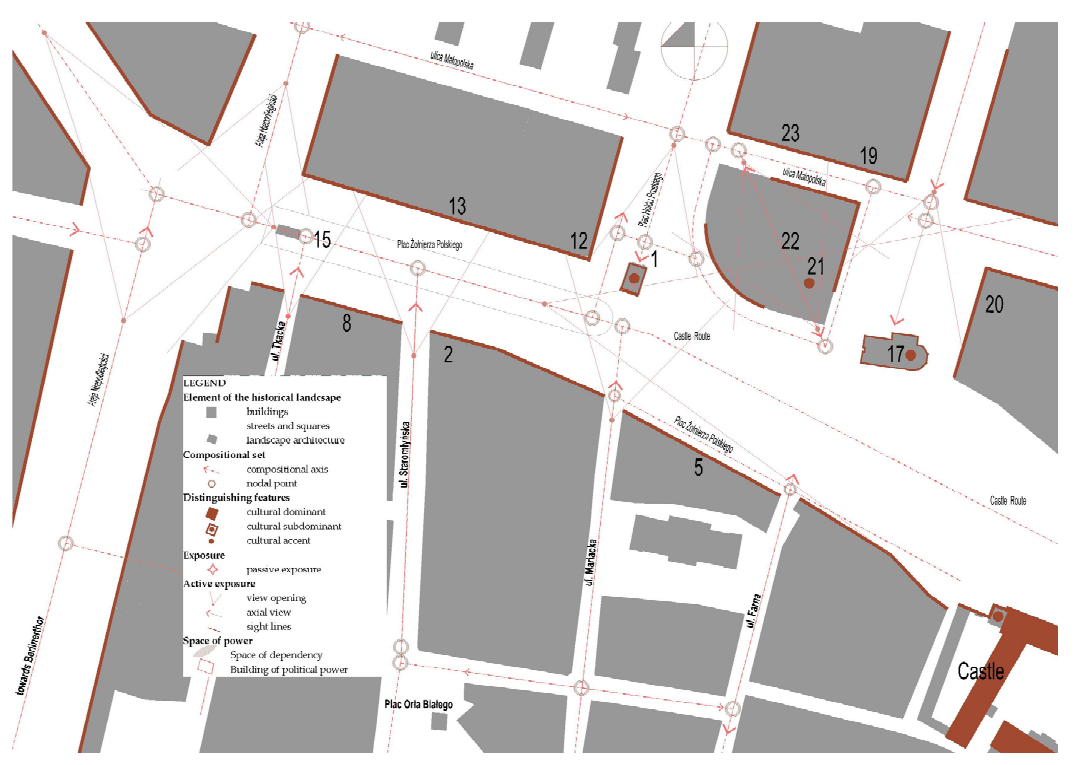

Figure 11. Landscape analysis of plac Żołnierza Polskiego in 2020. The spatial arrangement was corrected in relation to Figure 10. The public space was moved from plac Żołnierza Polskiego into the space of plac Solidarności. The main compositional axis of this urban interior run diagonally, linking the new philharmonic building (23) with the spatial accent-the castle tower. The space of authority around both urban interiors was eliminated as a result of it being given new public functions $(12,13,19)$. Despite the development of aleja Kwiatowa (15), plac Żołnierza Polskiego has a dominant function of communication in its central part. Plac Solidarności has thus become a space of post-dependence and emancipation (source: created by author). 
Plac Solidarności was given a unique form, and the roof of the underground Pavilion of the DCU was used for the topographical arrangement of the urban space. According to architects, the design of the DCU building, based on the idea of 'topography,' was to "blur the architecture at the site, so people cannot see the boundaries of the architectural facility, and they can hardly distinguish where the site ends and the facility begins" (https://www.bryla.pl/bryla/1,90857,13583450,Niektorzy_architekci_ tworzaprojekty_topograficzne.html (accessed on 1 November 2020)) (Konieczny 2013). This created a new city forum with a theatrical arrangement, ensuring intimacy for social activities. At the same time, it was isolated from plac Żołnierza Polskiego, which is now dominated by the public transport system.

Plac Solidarności is now a multifunction space of emancipation, a place for recreation (cycling, rollerblading), peaceful demonstrations, and celebrations commemorating the historic events that are important to Szczecin. This is how a space of emancipation can serve as "a space for self-reaction and inventiveness" (Kowalewski 2018).

The space which has been created in this area of Szczecin is undoubtedly a place of satisfaction and pride, as well as a place where its inhabitants can discover and confront their identity.

Finally, the 'taming' of the German and Soviet heritage in Szczecin after 1989 should be mentioned. It is the need to deal with this heritage that may "testify to the post-colonial condition of the city" (Praczyk 2015). After 1989, while changes were made to the names of the city streets, no need for such measures was apparent in the area of plac Żołnierza Polskiego itself. The most important change that took place in the space adjacent to plac Żołnierza Polskiego was the removal, first of all, of the red star on the obelisk, and in 2017, the dismantling of the entire Monument of Gratitude to the Soviet Army. However, on the basis of street surveys, its removal was not deemed necessary; the inhabitants of Szczecin emphasised the need to preserve the monument in the city space as a witness to history. The red star became a part of the DCU Museum's exhibition, while the sculptures were displayed at the Main Cemetery in Szczecin. The German tradition, freed from the anti-German propaganda of Communist Poland (Praczyk 2015, p. 136), was also drawn into the symbolic urban space. One example is the reconstruction of the marble monument of Frederick the Great, which once stood in plac Żołnierza Polskiego and was destroyed during the wartime evacuations; it is now displayed in the courtyard of the National Museum (the former Landeshaus). The phenomenon of the acceptance and its extent of the German and Soviet heritage in the area of Szczecin is an interesting phenomenon, which would repay further, separate scientific research.

\section{Conclusions}

This article presents the process of architectural and urban development of plac Żołnierza Polskiego and Plac Solidarności from the first half of the 18th century to modern times. The transformations taking place in the spaces of both squares can be perceived as an evolution of the processes of social production of space (Lefebvre [1974] 1991). Nevertheless, important determinants leading to the creation of plac Żołnierza Polskiego (1736) and plac Solidarności (an undeveloped quarter following on from a former urban block, becoming Plac Solidarności in 1945/1989) were political factors, such as the takeover of Szczecin by the Prussian state in 1713, the change of statehood of the Western Pomeranian lands in 1945, and the decline of Soviet dependence in 1989. Spaces of dependence, initiated by geopolitical conditions, were formed by the representations of authority (regimes) and their ideologies (actor/ideology: the king, absolute monarchy/the so-called divine right of kings and the Communist government/Communist ideology).

Plac Żołnierza Polskiego was one such space of dependence, with its monumental, baroque buildings and monuments covered with rich decorations of symbolic meaning which were created as a space of prestige representing the domination of the new monarchy over the traditional space of the merchant city in the first half of the 18th century. Baroque architecture and urban planning were tools of state propaganda, used in order to create a 
Prussian identity for its inhabitants (a cultural process of colonizing the urban space). These spatial forms of power and symbolism were additionally strengthened by the expansion of modern fortifications that subjected the inhabitants of Szczecin to political and economic oppression until 1873.

The process of emancipating the space of plac Żołnierza Polskiego began with the emergence of neohumanism and a new actor in the space-the bourgeoisie (class system). Social changes generated new functions of buildings (theatres, operas and museums) and architectural forms (classical and Renaissance). One such building on plac Żołnierza Polskiego was the City Theatre, which opened in 1849. The next stage of emancipation in the economic and business field was the approval in 1873 (by the Prussian authorities, under pressure from Szczecin's political and economic circles) for the levelling of Szczecin's fortifications, which allowed a system of residential quarters to be built on the northern part of plac Żołnierza Polskiego. As a result of these changes, a representative public urban space was created, in which the spatial form of power was replaced by the forms of consumption and symbolism (Jałowiecki [1988] 2010).

The most important turning point for the space of plac Żołnierza Polskiego is 1945. Geopolitical changes in the 'Recovered Territories' related to the complete ethnic replacement of Szczecin's inhabitants initiated the process of 'marking' and assimilating the space as a Polish city (the process of 'cultural assimilation', 'symbolic colonization of the city', palimpsests, 're-coding architectural and urban structure', demolition and replacement of German monuments and changing of German-language toponyms and forms of signs) and building a Polish identity for Szczecin (propaganda of the 'Recovered Territories', historical politics, the 'policy of erasure' and 'making up traditions').

Szczecin's space of dependence during 1945-1989 (also understood as a confined space, a surveillance space, a Soviet space), which was subordinating and incapacitating in character, was a space created by an authoritarian state that held the monopoly on architecture and urban planning. The principles for the development of this space were governed by the ideas of a new social order (rejection of bourgeois tenement buildings, preference for new block housing development, the dominant role of vehicular traffic in urban planning, negation of the Prussian architecture of the 19th and 20th centuries, and the acceptance of Baroque architecture as 'pre-Prussian' with 'cosmopolitan form'). However, in conditions of dependence, disintegrated and antisocial spaces were created, with architecture subordinated to economic circumstances (the subordination of urban development to industrial functions, the five-year national development plan). The changes to the political and economic system in Poland after 1989 did not cause an immediate change in the use of space in Szczecin. The space of dependence was subject to a long process of evolution toward a space of emancipation (open space, space of choice), which depended on economic factors and the scale of deterioration of Szczecin's architectural and urban structure. The first stage, which aimed only at the development of 'small' architecture, was insufficient. Only inventive and self-created projects on the architectural and urban scale, connected with bottom-up initiatives, were able to change the space and create Szczecin's identity, in connection with the social movements of December 1970 and 1980. The space of dependence became a space of emancipation determined by categories of culture and value system.

Important elements of the squares in Szczecin included 'power structures,' understood as "objects of a more political nature than others" (Kurnicki 2015, p. 208). We agree with the opinion that "the political impact of a building depends on its use." This becomes an object of authority only in the context of the practices and functions it supports (Kurnicki 2015, p. 208). The architecture of power is illustrated by the centers of the Communist authorities based in the buildings located around plac Żołnierza Polskiego and plac Solidarności, representatives of Prussian architecture, which had different functions before 1939 and after 1989. According to the analysis of style, their architectural form was a strong vehicle for their identity (Prussian architecture in the post-war landscape of Szczecin). 
Under the influence of political tension, urban spaces become places for unique spatial practices (such as strikes, demonstrations, and, in extreme cases, armed campaigns (Szalewska 2013), recreation, cultural events, celebrations and meetings). These practices are concentrated in the strongest morphological points of the city-city squares (December 1970). They are often spaces of power, which bestows ideological content upon them and seals their formal code or style, which is considered to be an emanation of the governing power. However, such a space can become a space of value systems and cultural categories as a product of the emancipation process.

Author Contributions: Conceptualization, I.K. and E.K.; formal analysis, I.K. and E.K; funding acquisition, I.K.; investigation, I.K.; methodology, I.K. and E.K.; project administration, I.K.; visualization, I.K.; writing-original draft, I.K. and E.K; writing-review and editing, I.K. and E.K. All authors have read and agreed to the published version of the manuscript.

Funding: This research received no external funding.

Acknowledgments: Figures 1a, 3a and 4a used in the article are public domain.

Conflicts of Interest: The authors declare no conflict of interest.

\section{References}

Ackermann, Felix. 2010. Palimpsest Grodno. Nationalisierung, Nivellierung und Sowjetisierung Einer Mitteleuropäischen Stadt 1919-1991. Wiesbaden: Otto Harrassowitz GmbH \& Co. KG.

Archer, John. 2005. Social Theory of Space: Architecture and the Production of Self, Culture, and Society. Journal of the Society of Architectural Historians 64: 430-33. [CrossRef]

Bakuła, Bogusław. 2011. Studia postkolonialne w Europie Środkowej oraz Wschodniej 1989-2009. Kwerenda wybranych problemów w ramach projektu badawczego. In Kultura po Przejściach, Osoby z Przeszłościa. Polski Dyskurs Postzależnościowy—Konteksty i Perspektywy Badawcze. Edited by Ryszard Nycz. Kraków: Towarzystwo Autorów i Wydawców Prac Naukowych Universitas, vol. 1, pp. 137-66. ISBN 97883-242-1549-2.

Balke, Franz. 1929. Das Denkmal Friedrichs des Grossen von Schadow. Stettin: Fischer \& Schmidt.

Bańka, Augustyn. 2009. Architektura Psychologicznej Przestrzeni Życia. Behawioralne Podstawy Projektowania. Poznań: Stowarzyszenie Psychologii i Architektury-Poznań. ISBN 978-83-62051-76-2.

Berghaus, Heinrich Karl Wilhelm. 1876. Geschichte der Stadt Stettin, der Hauptstadt von Pommern. Berlin: Writzen/O, vol. 9.

Birch, Eugenie. 2007. Public and Private Space in Urban Areas: House, Neighborhood, and City. In Handbook of Community Movements and Local Organizations. Edited by Ram Cnaan and Carl Milofsky. New York: Springer, pp. 118-28.

Borkowska, Małgorzata. 1977. Zespót Pałacowy przy pl. Żołnierza Polskiego nr 2 i ul. Staromtyńskiej 1 w Szczecinie. Szczecin: Typescript in the collections of the Provincial Office for the Protection of Monuments.

Borkowski, Michał. 1950. O dalsze pogłębienie przełomu w dziedzinie projektowania i na budowie—Rezolucja VI Zjazdu Naukowego P. Z. I. T. B. w Gdańsku, przyjęta w dniu 4 grudnia 1949. Wrażenia z VI Zjazdu Naukowego w Gdańsku. Architektura 4: 1-4.

Cavanagh, Clare. 2003. Postkolonialna Polska. Biała plama na mapie współczesnej teorii. Teksty Drugie 2-3: 60-71.

Cavanagh, Clare. 2004. Postcolonial Poland. Common Knowledge. Winter 10: 82-92.

Corbusier, Le. 2017. Karta Ateńska. Warszawa: Centrum Architektury. ISBN 9788394375065.

Czaplicki, John. 2003. The Archeology of the Local. Introdaction. In Composing Urban History and the Constitution of Civic Indentities. Edited by John Czaplicki and Blair A. Ruble. Washington, DC: Woodrow Wilson Centre Press with Johns Hopkins University, pp. 25-29. ISBN 978-0-8018-7385-0.

Dettloff, Paweł. 2012. Postrzeganie i ochrona dziedzictwa kulturowego w Polsce w XX wieku a konsekwencje kolonializmu i doświadczenia totalitaryzmu. In Perspektywa (post)kolonialna w Kulturze. Szkice i Rozprawy. Edited by Ewa Partyga, Joanna M. Sosnowska and Tadeusz Zadrożny. Warszawa: Oficyna Wydawnicza Errata, pp. 69-89. ISBN 978-83-60950-84-5.

Francis, Mark. 1989. Control as a dimensionof public-space quality. In Public Places and Spaces. Edited by Irwin Altmanand and Ervin Zube. New York: Plenum, pp. 147-72.

Fredrich, Carl. 1920. Die ehemalige Marienkirche in Stettin und ihr Besitz. T. 2 W: BSt NF Bd. XXIII. Stettin: Leon Saunier.

Friedrich, Jacek. 2012. Spolszczanie i odniemczanie sztuki i architektury Gdańska po 1945 roku. Kolonizacja czy dekolonizacja? In Perspektywa (post)kolonialna w kulturze. Szkice i rozprawy. Edited by Ewa Partyga, Joanna M. Sosnowska and Tadeusz Zadrożny. Warszawa: Oficyna Wydawnicza Errata, pp. 127-45. ISBN 978-83-60950-84-5.

Fritsch, Georg. 1931. Johan Arnold Nering. In Allgemeines Lexikon der Bildenden Künstler von der Antike bis zur Gegenwart. Edited by Ulrich Thieme and Felix Becker. Leipzig: Seemann, vol. 25.

Golinczak, Michalina. 2008. Postkolonializm. Przed Użyciem Wstrząsnać. Recykling Idei. vol. 10. Available online: http:/ / katalog.czasopism.pl/index.php/Recykling_Idei_-_Michalina_Golinczak,_POSTKOLONIALIZM:_PRZED_U\%C5 \%BBYCIEM_WSTRZ\%C4\%84SN\%C4\%84\%C4\%86! (accessed on 8 February 2021). 
Goss, Jon. 1988. The built environment and social theory: Towards an architectural geography. Professional Geographer 40: $392-403$. [CrossRef]

Grabkowska, Maja. 2017. Przestrzeń miasta postsocjalistycznego jako dobro wspólne. Przegląd koncepcji teoretycznych. Prace Geograficzne 149: 33-53.

Grzelak, Jerzy. 2013. Wizja szaty ideologicznej miasta w koncepcji urbanistyki socjalistycznej na przykładzie nazw ulic i placów Szczecina w latach 1945-1990". In Pod dyktando Ideologii. Studia z Dziejów Architektury i Urbanistyki w Polsce Ludowej. Edited by Paweł Knap. Szczecin: Instytut Pamięci Narodowej Szczecin, pp. 371-97. ISBN 9788361336020.

Gwiazdowska, Ewa. 2001. Widoki Szczecina. Źródła Ikonograficzne do Dziejów Miasta XVI Wieku do 1945 Roku. Szczecin: Muzeum Narodowe w Szczecinie. ISBN 83-86136-11-1.

Hall, Edward Twitchell. 1969. The Hidden Dimension. New York: Doubleday. ISBN 9780385084765.

Hannertz, Ulf. 2006. Odkrywanie Miasta. Antropologia Obszarów Miejskich. Kraków: Wydawnictwo Uniwersytetu Jagiellońskiego. ISBN 83-233-2187-6.

Harvey, David. 2012. Rebel Cities: From the Right to the City to the Urban Revolution. London and New York: VERSO. ISBN 978-1-84467904-1.

Hasselgren, Sven. 1972. The Language of Architecture. London: Applied Science Publishers.

Hillier, Bill, and Julienne Hanson. 1984. The Social Logic of Space. Cambridge: Cambridge University Press. ISBN 9780511597237.

Hobsbawm, Eric. 2008. Wprowadzenie. Wynajdywanie tradycji. In Tradycja Wynaleziona. Edited by Eric Hobsbawm and Terence Ranger. Kraków: Wydawnictwo Uniwersytetu Jagiellońskiego, pp. 9-23. ISBN 978-83-233-2455-3.

Jackson, Kenneth T. 1985. The Crabgrass Frontier. The Suburbanization of the United States. New York: Oxford University Press. ISBN 0-19-403610-7.

Jałowiecki, Bohdan. 2010. Społeczne Wytwarzanie Przestrzeni. Warszawa: Wydawnictwo Naukowe SCHOLAR. ISBN 978-83-7383-396-8. First published 1988.

Janion, Maria. 2003. Polska między Wschodem a Zachodem. Teksty Drugie 4: 19-42.

Kajzerek, Agata. 1946. Drogowskazy zachodnie. Odra. Tygodnik Literacko-Społeczny $42: 7$.

Kiossev, Alexander. 1999. Notes on Self-Colonizing Cultures. In After the Wall. Art and Culture in PostCommunist Europe. Edited by Bojana Pejic and David Elliott. Stockholm: Moderna Museet, pp. 114-18.

Kołodziejczyk, Dorota. 2011. Postkolonialny transfer na Europę Środkowo-Wschodnią. In Kultura po Przejściach, Osoby z Przeszłościa. Polski Dyskurs Postzależnościowy—Konteksty i Perspektywy Badawcze. Edited by Ryszard Nycz. Kraków: Towarzystwo Autorów i Wydawców Prac Naukowych Universitas, vol. 1, pp. 117-36. ISBN 97883-242-1317-7.

Kołodziejczyk, Dorota. 2013. Gdzie jest miejsce dla Europy Środkowej i Wschodniej w przestrzeni postkolonialnej? Możliwe trajektorie podróży. Porównania 13: 9-27.

Konieczny, Robert. 2013. Niektórzy Architekci Tworza_Projekty Topograficzne KWK PROMES. Available online: https:/ / www.bryla.pl/ bryla/1,90857,13583450,Niektorzy_architekci_tworza__projekty_topograficzne.html (accessed on 8 February 2021).

Kotkin, Joel. 2005. The City. New York: Modern Library. ISBN 0679603360.

Kowalewski, Maciej, Eryk Krasucki, and Paweł Miedziński. 2010. Historia, Miasto, Pamięć. Grudzień 70-Styczeń 71. Szczecin: Instytut Pamięci Narodowej. ISBN 978-83-6133-613-6.

Kowalewski, Maciej. 2018. Emergent political spaces in the post-socialist city: Solidarity Square, Szczecin. Space and Polity 22: $42-49$. [CrossRef]

Kozińska, Bogdana. 2002. Rozwój Przestrzenny Szczecina od Początku XIX Wieku do II Wojny Światowej. Szczecin: KAMPOL. ISBN 8388341-10-3.

Kozłowska, Izabela. 2007. Szczecińskie Fortyfikacje Nowożytne. Rola Fortyfikacji Nowożytnych w Kształtowaniu układu Przestrzennego Miasta Szczecina oraz Wpływ Analizy Historycznej na Współczesne Działania Projektowe i Zakres Ochrony Konserwatorskiej, Rozprawa Doktorska. Ph.D. thesis, Politechnika Gdańska, Wydział Architektury. Available online: https: / / pbc.gda.pl/dlibra/doccontent?id=8063 (accessed on 1 November 2020).

Kozłowska, Lidia. 1993. Karta Ewidencyjna Zabytku Architektury i Budownictwa, Budynek 13 Muz. Typescript in the collections of the Provincial Office for the Protection of Monuments. Szczecin: The Provincial Office for the Protection of Monuments.

Krasucki, Eryk. 2017. Die Dezember-Revolte und die Stettiner Identität. In Stettin. Wiedergeburt einer Stadt. Essays über die Odermetropole. Edited by Basil Kerski. Potsdam: Deutsches Kulturforum östliches Europa, pp. 157-69. ISBN 978-3-936168-74-7.

Kroman, Krystyna. 1992. Dzieje architektury zamku od schyłku średniowiecza po czasy współczesne. In Zamek Ksiązęcy w Szczecinie. Edited by Janina Kochanowska. Szczecin: Wydawnictwo GLOB.

Kubiak, Adam. 2018. Postkolonialne Polski: Szkic z niepewnej natury/Postcolonial Polands—An outline of uncertain nature. Polonistyka. Innowacje 8: 99-115. [CrossRef]

Kubowska, Elżbieta. 2017. Maszt Maciejewicza na Łasztowni? 24 Kurier Szczeciński. Available online: https://24kurier.pl/aktualnosci/ wiadomosci/maszt-maciejewicza-na-lasztowni (accessed on 1 November 2020).

Kunicki, Kazimierz, and Tomasz Ławecki. 2015. Kronika PRL Ziemie Odzyskane. Warszawa: Edipresse Kolekcje. ISBN 978-83-7989-446-8.

Kurnicki, Karol. 2015. Ideologie w Mieście: O Społecznej Produkcji Przestrzeni. Ph.D. thesis, Uniwersytet Jagielloński, Instytut Socjologii, Kraków, Poland. Available online: https://ruj.uj.edu.pl/xmlui/bitstream/handle/item/42263/Kurnicki_Ideologie_ w_miescie_o_spolecznej_produkcji_przestrzeni_2015.pdf?sequence=1\&isAllowed=y (accessed on 1 November 2020).

Labuda, Gerard. 1994. Dzieje Szczecina: Wiek X-1805. Warszawa-Poznań: Państwowe Wydawnictwo Naukowe. ISBN 8301043423. 
Lees, Loretta. 2001. Towards a critical geography of architecture: The case of an ersatz colosseum. Ecumene 8: 51-86. [CrossRef]

Lefebvre, Henri. 1991. The Production of Space. Oxford: Blackwell Publishing. ISBN 0-631-18177. First published 1974.

Lefebvre, Henri. 1996. The Right to the City. Available online: https://theanarchistlibrary.org/library/henri-lefebvre-right-to-the-city (accessed on 8 February 2021).

Lisiak, Agata. 2009. (Post)kolonialne miasta Europy Środkowej. Porównania 6: 137-48.

Łopuch, Wojciech. 1999. Dzieje Architektoniczne Nowoczesnego Szczecina 1808-1945. Szczecin: Książnica Pomorska. ISBN 83-87879-07-X.

Lorne, Colin. 2017. Spatial agency and practising architecture beyond buildings. Social E Cultural Geography 18: $268-87$.

Moore, David Chioni. 2001. Is the Post- in the Postcolonial the Post- in Post-Soviet? Toward a Global Postcolonial Critique. PMLA 116: 111-28. [CrossRef]

Musekamp, Jan. 2015. Między Stettinem a Szczecinem. Metamorfoza Miasta od 1945 do 2005. Poznań: Nauka i Innowacje. ISBN 978-8363795-22-1.

Nekanda-Trepka, Janusz. 2017. Kształtowanie krajobrazu kulturowego Szczecina-Centrum Dialogu Przełomy. Biuletyn Informacyjny PKN ICOMOS 1: 16-25.

Niezabitowska, Elżbieta. 2006. Wybrane aspekty problematyki przestrzeni w architekturze. Zeszyty Naukowe. Architektura/Politechnika Śląska 44: 135-38.

Nora, Pierre. 1984. Entre Mémoire et Histoire. La Probelmatique des lieux. In Lieux de Mémoire. Paris: La République, vol. 1, pp. XVII-XLII.

Nycz, Ryszard. 2011. Wprowadzenie. “Nie leczony, chroniczny pogłos”. Trzy uwagi o polskim dyskursie postzależnościowym. In Kultura po Przejściach, osoby z Przeszłościa. Polski Dyskurs Postzależnościowy—Konteksty i Perspektywy Badawcze. Edited by Ryszard Nycz. Kraków: Towarzystwo Autorów i Wydawców Prac Naukowych Universitas, vol. 1, pp. 7-12. ISBN 97883-242-1317-7.

Omilanowska, Małgorzata. 2010. Post-totalitarian and post-colonial experience. The Palace of Culture and Science and Defilad Square in Warsaw. In The Post-Socialist City: Continuity and Change in Urban Space and Imagery. Edited by Alfrun Kliems and Marina Dmitrieva. Berlin: Jovis Verlag, pp. 120-39. ISBN 978-3-86859-018-0.

Osęka, Piotr. 2007. Rytuały Stalinizmu. Oficjalne Święta i Uroczystości Rocznicowe w Polsce 1944-1956. Warszawa: Wydawnictwo Trio. ISBN 978-83-7436-091-3.

Paszkowski, Zbigniew. 2008. Restrukturyzacja Miasta Historycznego Jako Metoda Jego Współczesnego Kształtowania na Przykładzie Starego Miasta w Szczecinie. Szczecin: Wydawnictwo Hogben. ISBN 978-83-60637-28-9.

Pazder, Dominika. 2008. Rola przestrzeni kulturowych w kreacji współczesnego śródmieścia. Czasopismo Techniczne 4-A: 21-26.

Piskorski, Czesław. 1960. Szczecin i Okolice. Warszawa: Sport i Turystyka.

Podlewski, Wacław. 1948. Zagadnienia odbudowy miast zabytkowych Pomorza Zachodniego. Ochrona Zabytków 1: 110-14.

Praczyk, Małgorzata. 2015. Materialne ślady minionej zależności i ich współczesne odczytanie w przestrzeni miejskiej Szczecina. Porównania 17: 123-38. [CrossRef]

Przybył-Sadowska, Elżbieta, Jakub Sadowski, and Dorota Urbanek. 2016. Rosja Przestrzeń, Czas i Znaki. Kraków: Wydawnictwo LIBRON-Filip Lohner.

Ptaszyński, Radosław. 2009. Przeklęty plac. Pamięć i Przeszłość 4: 26-29.

Rajewski, Adam. 2013. Kultura historyczna jako kategoria badań nad obecnościa przeszłości w teraźniejszości. Propozycje teoretyczne Petera O. Loewa. Rocznik Antropologii Historii 1: 357-64.

Raszka, Helena. 1981. Daty, wydarzenia, wiersze. Morze i Ziemia 2: 46-49.

Rek-Lipczyńska, Agnieszka, and Izabela Kozłowska. 2019. Przestrzeń pamięci-Pamięć przestrzeni. Refleksja nad przestrzeniami symbolicznymi miasta Szczecin w świetle postmodernistycznej transformacji sztuki i architektury. Pamiętnik Sztuk Pięknych 14: $51-58$.

Rewski, Zbigniew. 1949. O odprusaczaniu architektury Ziem Zachodnich. Odra 7: 2.

Rzempołuch, Andrzej. 2002. Architektura dworska w Prusach Książęcych i na Warmii. Studium genezy i odrębności. Roczniki Humanistyczne 4: 197-246.

Sachanowicz, Tomasz. 2012. Nowy pawilon promuje Szczecin. Mieszkańcy: “szklana pułapka”, “akwarium”. Bryła.pl. 16-10-2012. Available online: https: / www.bryla.pl/bryla/1,85301,12633794,nowy-pawilon-promuje-szczecin-mieszkancy-szklana-pulapka. $\mathrm{html}$ (accessed on 1 November 2020).

Sakson, Andrzej. 2020. Nowe Społeczeństwo Ziem Zachodnich i Pótnocnych (1945-2020). Poznań: Uniwersytet im. Adama Mickiewicza, Wydawnictwo Naukowe Wydziału Nauk Politycznych i Dziennikarstwa. ISBN 978-83-65817-29-7.

Schlögel, Karl. 2001. Promenade in Jalta und Andere Städtebilder. München: Carl Hanse. ISBN 344620005.

Schlögel, Karl. 2016. In Space We Read Time: On History of Civilization and Geopolitics. Chicago: The University of Chicago Press. ISBN 9781941792094.

Schneider, Tatjana, and Jeremy Till. 2009. Beyond Discourse: Notes on Spatial Agency. FOOTPRINT. Delft School of Design Journal. Agency in Architecture: Reframing Criticality in Theory and Practice 4: 97-112.

Skórczewski, Dariusz. 2008. Postmodernizm, dekolonizacja i europocentryzm. O niektórych problemach teorii postkolonialnej i jej polskich perspektywach. Teksty Drugie 1-2: 33-55.

Słomiński, Maciej. 1987. Szczecińskie budowle Gerharda Corneliusa von Walrawe. Przegląd Zachodniopomorski 3: 109-20.

Słomiński, Maciej, Rafał Makała, and Małgorzata Paszkowska. 2000. Szczecin barokowy. Architektura lat 1630-1780. Szczecin: Stowarzyszenie Historyków Sztuki, Oddział w Szczecinie. 
Soja, Edward. 1996. Thirdspace, Journeys to Los Angeles and other Real-and-Imagined Places. Oxford: Blackwell Publisher. ISBN 978-1-55786674-5.

Stępiński, Włodzimierz. 1994. Życie obyczajowe i towarzyskie. Kultura umysłowa. In Dzieje Szczecina. Edited by Bogdan Wachowiak. Szczecin: Wydawnictwo, $13 \mathrm{Muz}^{\prime}$, pp. 227-38. ISBN 83-901159-1.

Sternicki, Andrzej. 2000. Trasa Zamkowa. In Encyklopedia Szczecina. Edited by Tadeusz Białecki. Szczecin: Uniwersytet Szczeciński, pp. 540-41. ISBN 83-7241-089-5.

Szalewska, Katarzyna. 2013. Antropologia przestrzeni miejskiej w kontekście polskiego dyskursu postzależnościowego. In $(P)_{O}$ zaborach, (p)o wojnie, $p($ o) PRL. Polski Dyskurs Postzależnościowy Dawniej i Dziś. Edited by Ewa Gosk and Hanna Kraskowska. Kraków: Towarzystwo Autorów i Wydawców Prac Naukowych Universitas, vol. 3, pp. 345-62. ISBN 97883-242-2244-5.

Szkudlarek, Tomasz. 1993. Postkolonializm jako dyskurs tożsamości. W stronę implikacji dla polskich dyskusji edukacyjnych. In emphSpory o Edukacje. Dylematy i Kontrowersje We Współczesnych Pedagogiach. Edited by Zbigniew Kwieciński and Lech Witkowski. Warszawa: Instytut Badań Edukacyjnych.

Szkudlarek, Tomasz. 1995. Dialektyka Innego i postkolonialna tożsamość. In Edukacja a Tożsamość Etniczna. Edited by Marta Urlińskia. Toruń: UMK.

Thiede, Fr. 1849. Chronik der Stadt Stettin. Stettin: Verlag von Ferdinand Müller.

Thompson, Ewa. 2000. Trubadurzy Imperium. Literatura Rosyjska i Kolonializm. Kraków: Towarzystwo Autorów i Wydawców Prac Naukowych Universitas. ISBN 97883-242-2729-7.

Thompson, Ewa. 2005. Said a sprawa polska. Europa. Tygodnik Idei 26: 11.

Tołwiński, Tadeusz. 1948. Urbanistyka, T.1. Budowa Miasta w Przeszłości. Warszawa: Trzaska, Evert i Michalski.

Tuan, Yi-Fu. 1983. Moral ambiguity in architecture. Landscape 27: 11-17.

Üngür, Erdem. 2011. Space: The undefinable space of architecture. Conference: Theory for the Sake of the Theory: ARCHTHEO '11. Available online: https://www.researchgate.net/publication/321155578_Space_The_undefinable_space_of_architecture (accessed on 8 February 2021).

Walkiewicz, Radosław. 2013. Gmach Wojewódzkiej Komendy Policji przy ul. Małopolskiej 47 w Szczecinie, Dawne Królewskie Prezydium Policji (niem. Königliches Polizei-Präsidium), Typescript in the collection of the Municipal Conservator of Monuments in Szczecin.

Wehrmann, Martin. 1911. Geschichte der Stadt Stettin. Stettin: Léon Sauniers.

Wejchert, Kazimierz. 1984. Elementy kompozycji urbanistycznej. Warszawa: Wydawnictwo Arkady. ISBN 978-83-213-4494-2.

Wierzejska, Jagoda. 2014. Hermeneutyka przestrzeni postsowieckiej. Próba zarysu. In Historie, Spoełczeństwa, Przestrzenie Dialogu. Studia Postzależnościowe w Perspektywie Porównawczej. Edited by Hanna Gosk and Dorota Kołodziejczyk. Kraków: Towarzystwo Autorów i Wydawców Prac Naukowych Universitas, vol. 4, pp. 405-22. ISBN 97883-242-2360-2.

Zachwatowicz, Jan. 1948. Pomniki kultury polskiej na Ziemiach Odzyskanych-Ich losy, ochrona i upowszechnieni. Przeglą Budowlany. Miesięcznik Poświęcony Sprawom Budownictwa. Organ Stowarzyszenia Zawodowego Przemysłowców Budowlanych R.P. 7: 244-54.

Zaremba, Piotr. 1980. Wspomnienia Prezydenta Szczecina 1945-1950. Poznań: Wydawnictwo Poznańskie. ISBN 83-210-0113-0. 